\title{
An Application of a Hybrid MCDM Method for the Evaluation of Entrepreneurial Intensity among the SMEs: A Case Study
}

\author{
Reza Rostamzadeh,, ${ }^{1,2}$ Kamariah Ismail, ${ }^{1}$ and Hossein Bodaghi Khajeh Noubar ${ }^{2}$ \\ ${ }^{1}$ Department of Management, Universiti Teknologi Malaysia, 81310 Skudai, Johor, Malaysia \\ ${ }^{2}$ Department of Management, East Azarbaijan Science \& Research Branch, Islamic Azad University, Tabriz, Iran \\ Correspondence should be addressed to Kamariah Ismail; m-maria@utm.my
}

Received 14 February 2014; Accepted 30 June 2014; Published 10 August 2014

Academic Editor: Vincenzo Eramo

Copyright (C) 2014 Reza Rostamzadeh et al. This is an open access article distributed under the Creative Commons Attribution License, which permits unrestricted use, distribution, and reproduction in any medium, provided the original work is properly cited.

\begin{abstract}
This study presents one of the first attempts to focus on critical success factors influencing the entrepreneurial intensity of Malaysian small and medium sized enterprises (SMEs) as they attempt to expand internationally. The aim of this paper is to evaluate and prioritize the entrepreneurial intensity among the SMEs using multicriteria decision (MCDM) techniques. In this research FAHP is used for finding the weights of criteria and subcriteria. Then for the final ranking of the companies, VIKOR (in Serbian: VlseKriterijumska Optimizacija I Kompromisno Resenje) method was used. Also, as an additional tool, TOPSIS technique, is used to see the differences of two methods applied over the same data. 5 main criteria and 14 subcriteria were developed and implemented in the real-world cases. As the results showed, two ranking methods provided different ranking. Furthermore, the final findings of the research based on VIKOR and TOPSIS indicated that the firms A3 and A4 received the first rank, respectively. In addition, the firm A4 was known as the most entrepreneurial company. This research has been done in the manufacturing sector, but it could be also extended to the service sector for measurement.
\end{abstract}

\section{Introduction}

Today, small and medium-sized enterprises (SMEs) are the basis of the global economy and play a vital role in job creation. The vitality and success of SMEs are known as important features in measuring an economy's growth and future development [1]. In developing and emerging economies, SMEs and entrepreneurs play an important role as they represent a major source of employment and generate significant revenue and export earnings [2]. Small firms depend on entrepreneurs to get a firm off the ground. Although SMEs typically face considerable resource constraints, they are often successful innovators [3]. This is mainly because entrepreneurial SMEs are nimbler than their larger counterparts; they can move faster and are more flexible, proactive, and risk keen $[4,5]$. As an emerging research field, entrepreneurship has received much attention over the last few decades. However, there is a lack of consensus on what precisely are the critical factors affecting entrepreneurial intense. For example, previous entrepreneurship research has investigated opportunity identification processes [6], startup processes [7] exploitation processes [8], team formation processes [9], financing processes [10], entrepreneurial exits [11], and international entrepreneurship [12, 13]. Yet, little attention has been paid to entrepreneurial intensity (EI). The entrepreneurial intention has been investigated extensively in the West [14-17], though it still remains as an understudied area in Malaysia. Applying the Western studies in Malaysian context would certainly raise a question of their suitability and applicability. At the local setting, some studies are really needed to expand the pertinency and accuracy of the results [18]. This study presents one of the first attempts to focus on critical success factors (CSFs) influencing the EI of Malaysian SMEs as they attempt to expand internationally. A better understanding of the entrepreneurial process would provide an important contribution to the entrepreneurship evaluation literature, and the entrepreneurship intensity literature would benefit from an investigation of how CSFs of entrepreneurship contribute to the SMEs performance. Based on the identified gaps in the literature, the key research questions 
addressed in this study are as follows: what are the CSFs of the EI? What are the priority of these critical factors? And how are the importances and preferences of these factors affect each of them?

The multicriteria decision making (MCDM) approach is a suitable approach to evaluate critical success factors (CSFs) of $\mathrm{EI}$, as the nature of these evaluation models includes different perspectives and should address the allocation of limited resources. Tzeng and Huang [19] indicated that MCDM is a methodology that can consider multiple criteria at the same time [20] and helps the decision maker to estimate the best case according to the characteristics of limited available cases. The MCDM technique is a powerful tool widely used for evaluating and ranking problems containing multiple, usually conflicting, criteria. It includes several techniques, which allow rating a range of criteria and ranking them as a decision maker. It has great potential to reduce the cost and time and increase the accuracy of decisions and can be an appropriate framework for solving the problems. The concept of combining the fuzzy theory and MCDM is referred to as fuzzy MCDM (FMCDM).

The paper adds to the entrepreneurial evaluation literature in several ways. First, no prior study that we are aware of has examined critical factors of entrepreneurship as a driving force of entrepreneurial intensity. Second, few studies in the literature examine the performance of SMEs regarding this evaluation. The next contribution of this research is that there is no more study using MCDM in fuzzy environment to evaluate EI among the SMEs. This paper is intended to bridge these gaps. The remainder of the paper is as follows. In the next section, we review the existing literature. In Section 3, the methodologies such as FAHP, VIKOR, and TOPSIS are used to assess the criteria. Applications of the proposed methodologies in real-world situations and a comparison of the results are presented in Section 4. The results and discussion are discussed in Section 5. Finally, in Section 6, conclusion and future studies are given.

\section{Literature Review}

In this section, first available MCDM applications in the field of entrepreneurship and innovation are reviewed and then how to evaluate the EI is described.

2.1. MCDM Applications in the Field. Han et al. [21] developed an evaluation model based on fuzzy theory and analytic hierarchy process (AHP) for assessing entrepreneurial environment to help the government and entrepreneur in an interacted environment. This model provides a precise, effective, and organized decision support tool. The evaluation of entrepreneurial capacity of college students was done by Ni-Di and Yi [22]. The decision making method has been provided reasonably to pick the satisfactory selfemployed student. The outcomes show a greater weight on the dimension of entrepreneurial capacity of college student evaluation, and four critical evaluation criteria related to it are personal characteristics, personal qualities, personal abilities, and environment. Rezaei et al. [23] proposed four different methodologies for measuring the entrepreneurship, including the statistical methodology, a fuzzy logic, a data envelopment analysis (DEA), and a naïve methodology. As an expert-based methodology, fuzzy logic compensates some of the limitations of the statistical methodology. Drawing on a sample of 59 startups, they measured innovativeness, risk taking, and proactiveness and subsequently compared the resulting EO scores. A naïve methodology produces a value that lies between the other results, while the entrepreneurial score from a fuzzy logic methodology is the most dissimilar from the others. Most lately Rezaei et al. [24] applied an improved fuzzy AHP for ranking the firms based on their EO score. Same as their previous work [23], the three dimensions were used: innovativeness, risk taking, and proactiveness. The results specify that proactiveness is the most significant dimension, followed by innovativeness. Also, there are noticeable differences when it comes to the weights of the items. Lu et al. [25] used an AHP and fuzzy set theory, to assess a firm's technological innovation capability by several qualitative and quantitative criteria. Chen et al. [26] provided a quantitative MCDM approach to knowledge management in construction entrepreneurship education by means of an analytic knowledge network process (KANP). The study finds that there are eight clusters and 178 nodes in the KANP. The model and experimental research on the evaluation of teaching cases discloses that the KANP method is effective in conducting a knowledge management of the entrepreneurship education. Čančer and Knez-Riedl [27] presented a method for developing the internal ratings to best select among the business partners of a firm using AHP. Since qualitative factors come into play, special attention is given to determining not only quantitative but also qualitative criteria. Tsai and Kuo [1] applied a decision making trial and evaluation laboratory (DEMATEL), ANP, and zero-one goal programming (GP) methods, to measure entrepreneurship policies, using the Stevenson and Lundstrom [28] proposed criteria such as reducing entry and exit barriers, promotion, entrepreneurship knowledge, and financing and business support.

2.2. Entrepreneurial Intensity. In entrepreneurship research, entrepreneurial orientation (EO) has been found to have a positive impact on firm performance [29-35] and to be one of the most popular branches within entrepreneurship research [36]. Firms with high levels of EO tend to constantly scan and monitor their operating environment in order to find new opportunities and strengthen their competitive positions [37]. To define entrepreneurship, many authors [38-40] believe that entrepreneurship can be described as "the process of creating value by bringing together a unique combination of resources to exploit an opportunity." This definition exposes that the entrepreneurship may vary in terms of extent and the number of times it occurs. Several dimensions of EO have been proposed in which entrepreneurial intensity has been highlighted as the most important one. Miller [41] appears to offer the earliest operationalization of the EO concept and propose three-dimension proactiveness, risk taking, and innovativeness. Sexton and 
Morris [30] mention the varying levels of entrepreneurship as entrepreneurial intensity (EI). They view EI as a function of the degree and frequency of entrepreneurship as shown in Figure 1 [30]. This is supported by Antoncic and Hisrich [42]. On the other hand, Lumpkin and Dess [43] claimed that not three but five dimensions should be used to measure entrepreneurship, namely, autonomy, competitive aggressive, proactiveness, innovativeness, and risk taking. Also, Yang et al. [44] reviewed the literature of corporate entrepreneurship (CE) and explored the relationship between CE and market performance in China by taking a disaggregated approach after developing a reliable and valid scale of CE suggested by Antoncic and Hisrich [42]. They used venturing, innovation, self-renewal, proactiveness, and market performance as an evaluation scale. The results showed that each dimension exerts differentiated impacts on market performance of firms.

Frequency of entrepreneurship refers to the number of times an enterprise acts entrepreneurially while the degree of entrepreneurship is measured by three subdimensions: innovativeness, risk taking, and proactiveness. Kraus [45] investigated the role of the EO in service firms in Austria. A significant positive relationship between EO and corporate performance could be identified, with a clear emphasis on innovative behavior as the most important subdimension. Rigtering et al. [46] studied a comparative analysis of the $\mathrm{EO} /$ growth relationship with service and manufacturing firms using Miller's [41] dimensions. The findings showed that service firms have a significantly higher EO than manufacturing firms, both on the overall level and for each of the three dimensions. Scheepers et al. [47] compared the ebusiness EI of the Johannesburg Securities Exchange (JSE) and ICT companies. Company characteristics, organizational factors, and environmental factors were compared. It has been confirmed that EI varies among different industries or company groups. Erasmus and Scheepers [48] studied the relationship between EI and shareholder value creation. An adapted CE measurement instrument is applied in order to gauge EI, while shareholder value creation is measured by the market adjusted total share return (TSR) and the value based financial performance measure economic value added (EVA). The contribution of the study is the focus on the relationship between EI and shareholder value creation, rather than purely on the accounting-based financial performance of an enterprise. Keh et al. [35] studied the effects of $\mathrm{EO}$ and marketing information on the performance of SMEs among Singaporean. The results indicate that EO plays an influential role in the acquisition and utilization of marketing information and also has a direct effect on firm performance. The utilization of information regarding marketing mix decisions (particularly the promotion and place elements) positively affects firm performance, and it partially mediates the relationship between EO and firm performance. Related to entrepreneurial intentions, Lee et al. [49] investigated the influence of organizational and individual factors in Singapore. They examined why individuals intend to leave their jobs to start business ventures. Findings suggest that work environments with an unfavorable innovation climate and/or lack of technical excellence incentives influence entrepreneurial intentions, through low

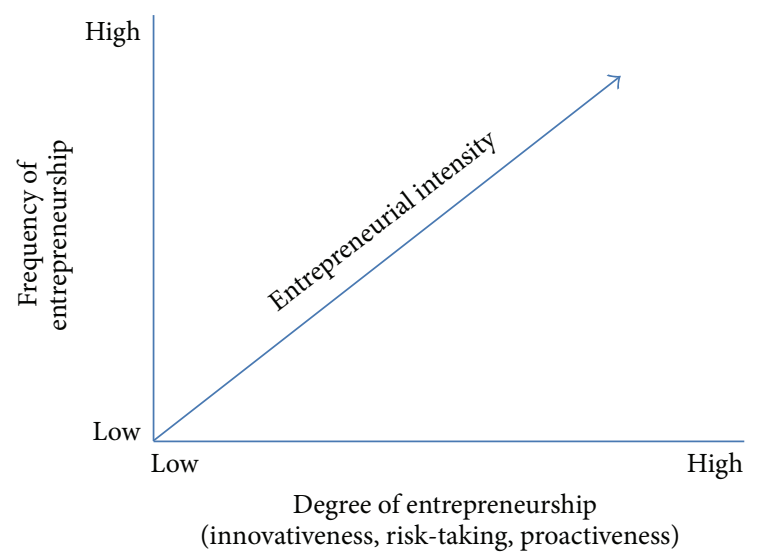

Figure 1: An illustration of entrepreneurial intensity.

job satisfaction. Cardon et al. [50] measured entrepreneurial passion (EP) and provided conceptual foundations and scale validation. They developed and validated an instrument to capture EP and its inherent dimensions. The results indicate that proper measurement of entrepreneurial passion incorporates the interaction between entrepreneurs' feelings and identity centrality for each domain.

The first subdimension, specifically innovativeness, refers to the creation of new products, services, and technologies. The second subdimension, risk taking, involves the willingness to commit significant resources to opportunities with a reasonable chance of costly failure. These risks are typically calculated and manageable. The third subdimension, proactiveness, reflects the top management orientation to pursuing enhanced competitiveness and includes initiative, competitive aggressiveness and boldness [51]. The forth subdimension, autonomy, refers to the independent action of an individual or a team in bringing forth an idea or a vision and carrying it through to completion. Generally, autonomy means the ability and will to be self-directed in the pursuit of opportunities.The fifth subdimension, competitive aggressiveness, refers to a firm's propensity to directly and intensely challenge its competitors to achieve entry or improve the position; EO literature agrees that a competitive aggressive orientation is one of the basic characteristics of successful entrepreneurial firm activity (e.g., $[29,43])$.

All the above-mentioned five dimensions have been used infrequently in the EO literature when compared with the use of the model with three dimensions. Rauch et al. [52] stated that only in one study [53] all these five dimensions have been used. However, in 30 studies [54-58], these same three dimensions have been used. In this research, we applied Lumpkin and Dess's dimensions and developed subcriteria for evaluating of EI in fuzzy environment.

\section{Fuzzy Set Theory}

3.1. FAHP. The Analytic hierarchy process (AHP) introduced by Saaty [59] directs how to determine the priority of a set of alternatives and the relative importance of attributes in 
a MCDM problems. Yang and Chen [60] stated that the classic AHP has some deficiencies. It is useful only when data are crispy, dealing with a very unbalanced scale of judgment; uncertainty of human judgment does not take into account of natural language; provided ranking is rather imprecise; and the subjective judgment of perception, evaluation, improvement, and selection based on preference of decision makers has great influence on the AHP results. To overcome such vagueness, ambiguity, and subjectivity of the human judgment process, fuzzy set theory has been introduced [61]. Decision makers express their opinions in terms of linguistic scales. Linguistic data are converted into fuzzy numbers with the help of different membership functions. Then, it becomes easy to solve MCDM problems. Therefore, fuzzy set theory has become a helpful tool for systematizing human activities with uncertainty-based information. As Ragin [62] stated, most scholars have not been familiar with the potential of fuzzy logic for transforming social science methodologies. Although it has great capability for dealing with vagueness problems in the field of innovation and entrepreneurship as a social science; yet we find a few applications in the existing studies.

A tilde " " will be placed above a symbol if the symbol represents a fuzzy set. A triangular fuzzy number (TFN) $\widetilde{M}$ is shown in Figure 2. A TFN is denoted simply as $(l \mid$ $m, m \mid u)$ or $(l, m, u)$. The parameter $l$ denotes the smallest possible value, the parameter $m$ the most promising value, and the parameter $u$ the largest possible value. Each TFN has linear representations on its left and right side such that its membership function can be defined as

$$
\mu(x \mid \widetilde{M})= \begin{cases}0, & x<l, \\ \frac{x-l}{m-l}, & l \leq x \leq m, \\ \frac{u-x}{u-m}, & m \leq x \leq u, \\ 0, & x>u .\end{cases}
$$

A fuzzy number can always be given by its corresponding left and right representation of each degree of membership:

$$
\begin{array}{r}
\widetilde{M}=M^{l(y)}, \quad M^{r(y)}=(l+(m-l) y, u+(m-u) y), \\
y \in[0,1] .
\end{array}
$$

There are many fuzzy AHP methods proposed by various authors [63-69]. The FAHP methodology is presented in the Appendix. The weights that are obtained from fuzzy AHP are considered and used in VIKOR and TOPSIS calculations.

3.2. VIKOR. Recently, the VIKOR method has been introduced as an applicable technique to implement within MCDM. Opricovic [70] developed VIKOR (VlseKriterijumska Optimizacija I Kompromisno Resenje) for multicriteria optimization of complex systems. This method determines the compromise solution and is able to establish the stability of decision performance by replacing the compromise solution obtained with initial weights. VIKOR can be divided

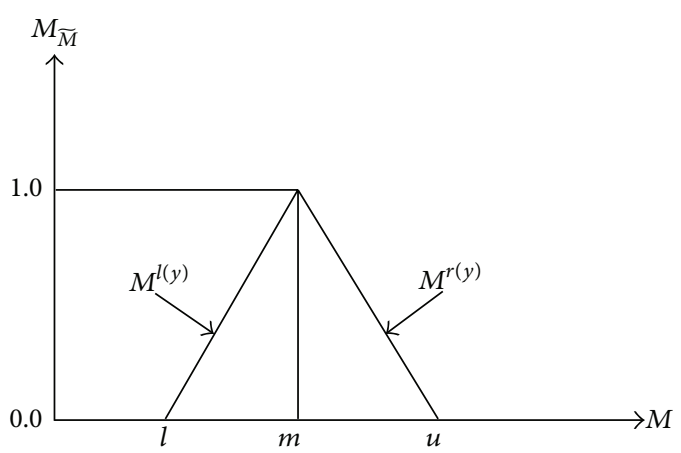

FIgURE 2: Triangular fuzzy number $\widetilde{M}$.

into the following steps [70-75] starting from $L_{p}$-metric used as an aggregating function in a compromise programming method [76, 77]:

$$
\begin{gathered}
L_{p i}=\left\{\sum_{j=1}^{n}\left[\frac{w_{j}\left(f_{j}^{*}-f_{i j}\right)}{f_{j}^{*}-f_{j}^{-}}\right]^{p}\right\}^{1 / p}, \\
1 \leq p \leq+\infty ; \quad i=1,2, \ldots I .
\end{gathered}
$$

In the VIKOR method, $\left(L_{1, i}\right.$ as $\left.S_{i}\right)$ and $\left(L_{\infty, i}\right.$ as $\left.R_{i}\right)$ are used to formulate ranking measure. The solution obtained by $\min S_{i}$ is with a maximum group utility ("majority" rule), and the solution obtained by $\min R_{i}$ is with a minimum individual regret of the "opponent." The algorithm of the VIKOR method has the following steps.

Step 1. Determine the best $f_{j}^{*}$ and the worst $f_{j}^{-}$values of all attribute functions, $j=1,2, \ldots, n$. If the $j$ th function represents a benefit, then we have

$$
f_{j}^{*}=\max \left(f_{i j}\right), \quad f_{j}^{-}=\min \left(f_{i j}\right)
$$

where $f_{j}^{*}$ is the positive ideal solution for the $j$ th criteria and $f_{j}^{-}$is the negative ideal solution for the $j$ th criteria. If one associates all $f_{j}^{*}$, one will have the optimal combination, which gets the highest scores, the same as $f_{j}^{-}$.

Step 2. Compute the values $S_{i}$ and $R_{i}, i=1,2, \ldots, m$ by

$$
\begin{aligned}
& S_{i}=\sum_{j=1}^{n}\left[\frac{w_{j}\left(f_{j}^{*}-f_{i j}\right)}{f_{j}^{*}-f_{j}^{-}}\right], \\
& R_{i}=\max _{j}\left[\frac{w_{j}\left(f_{j}^{*}-f_{i j}\right)}{f_{j}^{*}-f_{j}^{-}}\right],
\end{aligned}
$$

where $S_{i}$ denotes the distance rate of the $i$ th alternative to the positive ideal solution and $R_{i}$ represents the distance rate of the $i$ th alternative to the negative ideal solution. Also $w_{j}$ are the weights of criteria, expressing their relative importance. 
Step 3. Compute the values $Q_{i}, i=1,2, \ldots, m$ by

$$
Q_{i}=v \frac{S_{i}-S^{*}}{S^{-}-S^{*}}+(1-v) \frac{R_{i}-R^{*}}{R^{-}-R^{*}}
$$

where $S^{-}=\max _{i} S_{i}, S^{*}=\min _{i} S_{i}, R^{-}=\max _{i} R_{i}, R^{*}=\min _{i} R_{i}$, and $v$ is the weight of the strategy of "the majority of criteria" (or "the maximum group utility"); here suppose that $v=0.5$.

Step 4 (rank the alternatives). According to the $Q_{i}$ values calculated by Step 3, we can rank the alternatives to make decision.

Step 5. If the following two conditions are satisfied concurrently, then the scheme with a minimum value of $Q$ in ranking is considered the optimal compromise solution, such that

(C1) the alternative $Q\left(A^{(1)}\right)$ has an acceptable advantage, if $Q\left(A^{(2)}\right)-Q\left(A^{(1)}\right) \geq 1 / n-1$, where $A^{(2)}$ is the alternative with the second position in the ranking list by and $n$ is the number of alternatives;

(C2) the alternative $\mathrm{Q}\left(A^{(1)}\right)$ is stable within the decision making process if it is also best ranked in $S_{i}$ and $R_{i}$.

Step 6. Select the best alternative by choosing $Q\left(A^{(m)}\right)$ as a best compromise solution with the minimum value of $Q_{i}$ regarding the above conditions $[78,79]$.

3.3. TOPSIS. Hwang and Yoon [80] originally proposed the order performance technique based on similarity to ideal solution (TOPSIS), in which the chosen alternative should not only have the shortest distance from the positive ideal reference point (PIRP), but also have the longest distance from the negative ideal reference point (NIRP), to solve the MCDM problems.In the following the steps of TOPSIS are given.

Step 7. Decision matrix is being normalized via

$$
r_{i j}=\frac{w_{i j}}{\sqrt{\sum_{j=1}^{J} w_{i j}^{2}}}, \quad j=1,2,3, \ldots, J, i=1,2,3, \ldots, n
$$

Step 8. The weighted normalized decision matrix is being formed by

$$
v_{i j}=w_{i} * r_{i j}, \quad j=1,2,3, \ldots, J, i=1,2,3, \ldots, n .
$$

Step 9. Positive ideal solution (PIS) and negative ideal solution (NIS) will be determined by

$$
\begin{aligned}
& A^{+}=\left\{v_{1}^{+}, v_{2}^{+}, v_{3}^{+}, \ldots, n\right\} \text { max values, } \\
& A^{-}=\left\{v_{1}^{-}, v_{2}^{-}, v_{3}^{-}, \ldots, n\right\} \text { min values. }
\end{aligned}
$$

Step 10. The distance of each alternative from PIS and NIS will be calculated:

$$
\begin{aligned}
& d_{i}^{+}=\sqrt{\sum_{j=1}^{n}\left(v_{i j}-v_{j}^{+}\right)^{2}}, \quad j=1,2, \ldots, J, \\
& d_{i}^{-}=\sqrt{\sum_{j=1}^{n}\left(v_{i j}-v_{j}^{-}\right)^{2}}, \quad j=1,2, \ldots, J .
\end{aligned}
$$

Step 11. The closeness coefficient of each alternative will be calculated:

$$
C C_{i}=\frac{d_{i}^{-}}{d_{i}^{+}+d_{i}^{-}}, \quad i=1,2, \ldots, J
$$

Step 12. By comparing $C C_{i}$ values, the ranking of alternatives is determined.

\section{Implication in Real-World Cases}

Malaysia is one of the countries that have an emerging economy. The number of companies is growing quickly and is now becoming a center of new business opportunities as international investors view Malaysia as the place to invest and establish their businesses. Therefore, the entrepreneurship development has become the key agenda which is evident by the introduction of mechanisms that cater to entrepreneurs [81]. In Malaysia, the government has created an enormous amount of funding towards the promotion of entrepreneurship especially for SMEs. The Malaysian government has been extremely encouraging entrepreneurship. Since the 1970s, the government has given due emphasis to increasing Malay ownership and participation in the corporate sector and high-income occupation as outlined in New Economic Policy of 1971 [82]. This objective is further charted and highlighted in the New Development Policy in 1991 through the establishment of Bumiputera Commercial and Industrial Community (BCIC), which is responsible for fostering and developing Malay and other Bumiputera groups as entrepreneurs and professionals [82]. The BCIC has been the main network through which the strengthening of entrepreneurship among the Malays in Malaysia has been encouraged. The establishment of the Ministry of Entrepreneur Development in 1995 clearly indicates the growing importance of the government role in the issue of entrepreneur development [83]. According to the Federation of Malaysian Manufacturer (FMM) directory reports, 34.7 percent of Malaysian SMEs have less than 50 employees, 32.1 percent have 51-150 employees and 33.2 percent of SMEs have more than 150 employees [84]. Hence, in this research, we studied the SMEs with less than 50 employees as they possess the highest percent among the others. In this section, we apply the aforesaid methodology to evaluate the critical factors of EI among the 30 SMEs and rank them based on VIKOR and TOPSIS methods. First data collection process and then the implementation of the methodology are presented. 
TABLE 1: Criteria and subcriteria considered to evaluate EI.

\begin{tabular}{|c|c|}
\hline Criteria & Subcriteria \\
\hline \multirow{3}{*}{ C1: autonomy } & C11: management style \\
\hline & C12: having ownership \\
\hline & C13: awareness of emerging technologies \\
\hline \multirow{2}{*}{$\begin{array}{l}\mathrm{C} 2: \\
\text { innovativeness }\end{array}$} & C21: technological innovation \\
\hline & C22: product/market innovation \\
\hline \multirow{3}{*}{ C3: risk taking } & C31: venturing into the unknown business \\
\hline & C32: heavy borrowing, \\
\hline & $\begin{array}{l}\text { C33: committing large portions of corporate } \\
\text { assets in uncertain environments }\end{array}$ \\
\hline \multirow{4}{*}{$\begin{array}{l}\text { C4: } \\
\text { proactiveness }\end{array}$} & $\begin{array}{l}\text { C41: being knowledgeable about current and } \\
\text { future customers' preferences }\end{array}$ \\
\hline & C42: developing plans \\
\hline & C43: commitment to exploiting opportunities \\
\hline & C44: anticipation of future demand \\
\hline \multirow{2}{*}{$\begin{array}{l}\text { C5: } \\
\text { competitiveness } \\
\text { aggressiveness }\end{array}$} & $\begin{array}{l}\text { C51: intensity of a firm's effort to outperform } \\
\text { industry rivals }\end{array}$ \\
\hline & $\begin{array}{l}\text { C52: adopting unconventional tactics to } \\
\text { challenge industry leaders }\end{array}$ \\
\hline
\end{tabular}

This research has been conducted in three stages. First, FAHP was applied for finding the final weights of main criteria and subcriteria. Next, VIKOR was used to rank the EI of the firms and finally TOPSIS technique was adopted to compare the results with VIKOR. To get the required data of FAHP, a questionnaire was distributed. The respondents of this research were managers, assistant managers, and analysts of companies. To determine the reliability of the questionnaire, Spearman rank correlation coefficient analysis was conducted. Reliability test of the questionnaire was done at $95 \%$ confidence coefficient level. As the results show, the questionnaire has acceptable reliability. The hierarchy of the problem can be found in Figure 4, which includes three levels. The top level of the hierarchy represents the ultimate goal of the problem, while the second level of the hierarchy consists of five main criteria, which are, namely, innovativeness, proactiveness, autonomy, competitive aggressiveness, and risk taking. At the third level, these criteria are decomposed into various subcriteria.

Five criteria and fourteen subcriteria are considered, as shown in Table 1. For weighting tables, linguistic scales are used as illustrated in Table 2. Then, the main criteria and subcriteria were calculated using FAHP. Fuzzy pairwise comparisons of the main criteria and subcriteria are given in Tables 3 and 4, respectively. In the end, final weights of criteria and subcriteria using FAHP is presented in Table 5.

4.1. Application of VIKOR. In this stage, VIKOR was used to rank the EI of the firms. For this reason, the managers of the company have grouped. Decision makers from different backgrounds may define different weight vectors. They usually cause not only the inexact evaluation but also serious persecution during the decision process. Then, linguistic variables for the criteria and subcriteria weights and also
TABLE 2: Linguistic scales of importance.

\begin{tabular}{lcc}
\hline $\begin{array}{l}\text { Linguistic scale for } \\
\text { importance }\end{array}$ & Triangular fuzzy scale & $\begin{array}{c}\text { Triangular fuzzy } \\
\text { reciprocal scale }\end{array}$ \\
\hline Equal & $(1,1,1)$ & $(1,1,1)$ \\
Weak & $(1 / 2,1,3 / 2)$ & $(2 / 3,1,2)$ \\
Fairly strong & $(3 / 2,2,5 / 2)$ & $(2 / 5,1 / 2,2 / 3)$ \\
Very strong & $(5 / 2,3,7 / 2)$ & $(2 / 7,1 / 3,2 / 5)$ \\
Absolute & $(7 / 2,4,9 / 2)$ & $(2 / 9,1 / 4,2 / 7)$ \\
\hline
\end{tabular}

the decision matrix are provided as shown in Tables 6 and 7 , respectively. The values for $S, R$, and $Q$ were calculated and summarized in ascending order as demonstrated in Tables 8 and 9 , consequently. Here, the calculation is given for the firm A1. Calculation of the others was done similarly.

Step 13. Determine the best $f_{j}^{*}$ and the worst $f_{j}^{-}$values as (4):

$$
\begin{aligned}
& f_{j}^{*}: 7867766787755868777 \\
& f_{j}^{-}: 1233222333312223223 .
\end{aligned}
$$

Step 14. Compute the values $S_{i}$ and $R_{i}$ by (5):

$$
\begin{aligned}
S_{1}= & 0.08 \times \frac{7-5}{7-1}+0.33 \times \frac{8-7}{8-2}+0.1 \times \frac{6-5}{6-3}+0.29 \\
& \times \frac{7-5}{7-3}+0.2 \times \frac{7-5}{7-2}+0.035 \times \frac{6-3}{6-2}+0.005 \\
& \times \frac{6-5}{6-2}+0.039 \times \frac{7-7}{7-3}+0.165 \times \frac{8-7}{8-3}+0.165 \\
& \times \frac{7-6}{7-3}+0.056 \times \frac{7-5}{7-3}+0.025 \times \frac{5-1}{5-1}+0.019 \\
& \times \frac{5-3}{5-2}+0.087 \times \frac{8-7}{8-2}+0.029 \times \frac{6-3}{6-2}+0.087 \\
& \times \frac{8-6}{8-3}+0.087 \times \frac{7-5}{7-2}+0.1 \times \frac{7-6}{7-2}+0.1 \times \frac{7-7}{7-3} \\
= & 0.026+0.054+0.033+0.145+0.08 \\
& +0.026+0.001+0+0.033+0.041+0.028 \\
& +0.025+0.012+0.014+0.021+0.034 \\
& +0.034+0.02+0=0.63, \\
R_{1} & \{0.026,0.054,0.033,0.145,0.08,0.026, \\
& 0.001,0,0.033,0.041,0.028,0.025, \\
& 0.012,0.014,0.0217,0.034,0.034,0.02,0\}=0.145
\end{aligned}
$$

Step 15. Compute the values $Q_{i}$ by (6):

$$
\begin{aligned}
Q_{1}= & 0.5 \times \frac{0.63-0.39}{1.78-0.39}+(1-0.5) \\
& \times \frac{0.145-0.072}{0.33-0.072}=0.227
\end{aligned}
$$


TABLE 3: Fuzzy pairwise comparisons of the main criteria.

\begin{tabular}{lccccc}
\hline Goal & Autonomy & Innovativeness & Risk taking & Proactiveness & Comp. aggr. \\
\hline Autonomy & $(1,1,1)$ & $(2 / 5,1 / 2,2 / 3)$ & $(1 / 2,1,3 / 2)$ & $(2 / 5,1 / 2,2 / 3)$ & $(2 / 5,1 / 2,2 / 3)$ \\
Innovativeness & $(3 / 2,2,5 / 2)$ & $(1,1,1)$ & $(3 / 2,2,5 / 2)$ & $(1 / 2,1,3 / 2)$ & $(3 / 2,2,5 / 2)$ \\
Risk taking & $(2 / 3,1,2)$ & $(2 / 5,1 / 2,2 / 3)$ & $(1,1,1)$ & $(2 / 5,1 / 2,2 / 3)$ & $(2 / 3,1,2)$ \\
Proactiveness & $(3 / 2,2,5 / 2)$ & $(2 / 3,1,2)$ & $(3 / 2,2,5 / 2)$ & $(1,1,1)$ & $(1,1,1)$ \\
Comp. aggr. & $(3 / 2,2,5 / 2)$ & $(2 / 5,1 / 2,2 / 3)$ & $(1 / 2,1,3 / 2)$ & $(1,1,1)$ & $(1,1,1)$ \\
\hline
\end{tabular}

From Table 9, it has been shown that the A3 is best ranked by $Q$ and also both $(\mathrm{C} 1)$ and $(\mathrm{C} 2)$ conditions are satisfied, meaning that $Q_{\mathrm{A} 25}-Q_{\mathrm{A} 3} \geq 1 / 30-1$ and also $\mathrm{A} 3$ is best ranked by $R$ and $S$. Therefore, A3 is the best selected company for the best compromise solution.
4.2. Application of TOPSIS. In this stage, TOPSIS was conducted for comparing the results with the VIKOR. After normalizing Table 7 via (7), $R$ will be obtained:

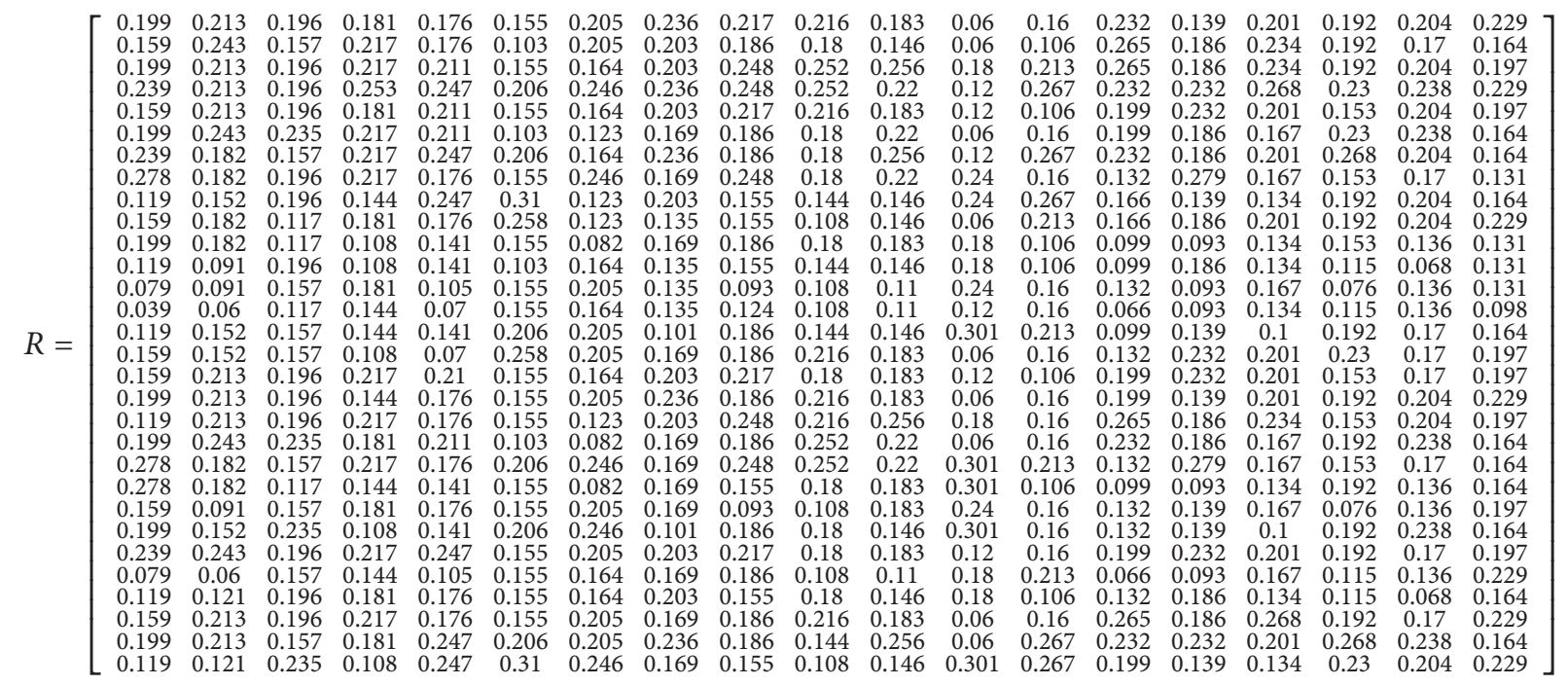

The weights that we obtained from FAHP were used to get the weighted decision matrix $V$. So, the weighted normalized decision matrix was formed by (8):

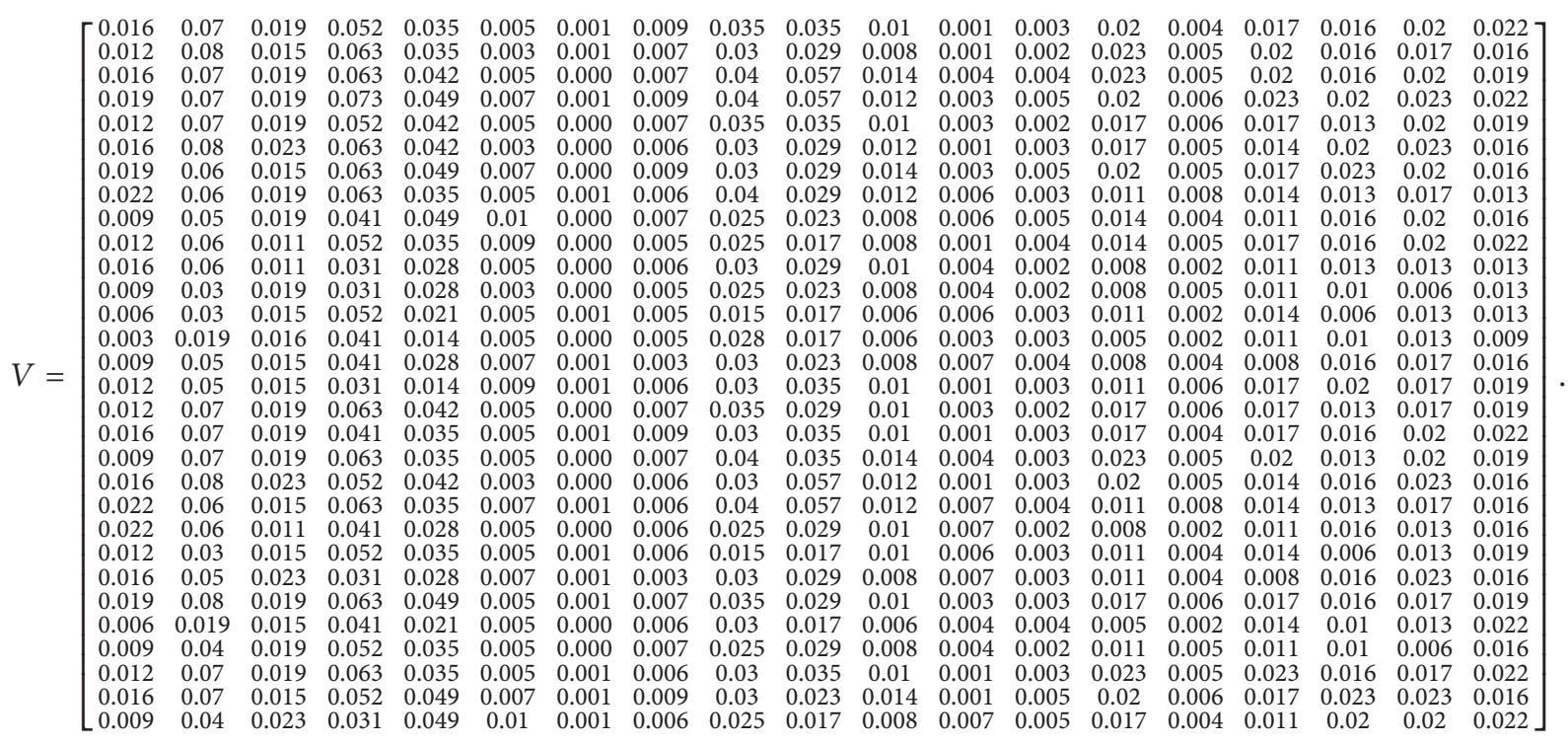


TABLE 4: Fuzzy pairwise comparisons of the subcriteria.

(a)

\begin{tabular}{lccc}
\hline Autonomy & Management style & Having ownership & Awareness of emerging technologies \\
\hline Management style & $(1,1,1)$ & $(1 / 2,1,3 / 2)$ & $(2 / 7,1 / 3,2 / 5)$ \\
Having ownership & $(2 / 3,1,2)$ & $(1,1,1)$ & $(2 / 5,1 / 2,2 / 3)$ \\
Awareness of emerging technologies & $(5 / 2,3,7 / 2)$ & $(3 / 2,2,5 / 2)$ & $(1,1,1)$ \\
\hline
\end{tabular}

(b)

\begin{tabular}{lcc}
\hline Innovativeness & Technological innovation & Product/market innovation \\
\hline Technological innovation & $(1,1,1)$ & $(1 / 2,1,3 / 2)$ \\
Product/market innovation & $(2 / 3,1,2)$ & $(1,1,1)$ \\
\hline
\end{tabular}

(c)

\begin{tabular}{lccc}
\hline Risk taking & Venturing into the unknown business & Heavy borrowing & Committing large portions \\
\hline Venturing into the unknown business & $(1,1,1)$ & $(3 / 2,2,5 / 2)$ & $(3 / 2,2,5 / 2)$ \\
Heavy borrowing & $(2 / 5,1 / 2,2 / 3)$ & $(1,1,1)$ & $(2 / 3,1,2)$ \\
Committing large portions & $(2 / 5,1 / 2,2 / 3)$ & $(1 / 2,1,3 / 2)$ & $(1,1,1)$
\end{tabular}

(d)

\begin{tabular}{lcccc}
\hline Proactiveness & Being knowledgeable & Developing plans & $\begin{array}{c}\text { Commitment to } \\
\text { exploiting opportunities }\end{array}$ & Anticipation of the future \\
\hline Being knowledgeable & $(1,1,1)$ & $(3 / 2,2,5 / 2)$ & $(1 / 2,1,3 / 2)$ & $(1 / 2,1,3 / 2)$ \\
$\begin{array}{l}\text { Developing plans } \\
\text { Commitment to }\end{array}$ & $(2 / 5,1 / 2,2 / 3)$ & $(1,1,1)$ & $(2 / 5,1 / 2,2 / 3)$ & $(2 / 5,1 / 2,2 / 3)$ \\
$\begin{array}{l}\text { exploiting opportunities } \\
\text { Anticipation of future }\end{array}$ & $(2 / 3,1,2)$ & $(3 / 2,2,5 / 2)$ & $(1,1,1)$ & $(1 / 2,1,3 / 2)$ \\
\hline
\end{tabular}

(e)

\begin{tabular}{lcc}
\hline Competitiveness aggressiveness & Intensity of a firm's effort & Adopting unconventional tactics \\
\hline Intensity of a firm's effort & $(1,1,1)$ & $(1 / 2,1,3 / 2)$ \\
Adopting unconventional tactics & $(2 / 3,1,2)$ & $(1,1,1)$ \\
\hline
\end{tabular}

Then positive ideal solution (PIS) and negative ideal solution (NIS) will be determined by (9):

$$
\begin{aligned}
A^{+}=\{0.022,0.08,0.023,0.073,0.049,0.01, & \\
& 0.001,0.009,0.04,0.057,0.014,0.007, \\
& 0.005,0.023,0.008,0.023,0.023,0.023,0.022\}, \\
A^{-}=\{0.003,0.019,0.011,0.031,0.014,0.003, & \\
& 0,0.003,0.015,0.017,0.006,0.001, \\
& 0.002,0.005,0.002,0.008,0.006,0.006,0.009\} .
\end{aligned}
$$

The distance of each alternative from PIS and NIS was calculated through (10):

$$
\begin{array}{lll}
d_{1}^{+}=0.038, & d_{2}^{+}=0.04, & d_{3}^{+}=0.02, \\
d_{4}^{+}=0.013, & d_{5}^{+}=0.039, & d_{6}^{+}=0.036, \\
d_{7}^{+}=0.039, & d_{8}^{+}=0.044, & d_{9}^{+}=0.062, \\
d_{10}^{+}=0.058, & d_{11}^{+}=0.066, & d_{12}^{+}=0.085,
\end{array}
$$

$d_{13}^{+}=0.084, \quad d_{14}^{+}=0.095, \quad d_{15}^{+}=0.067$,

$d_{16}^{+}=0.07, \quad d_{17}^{+}=0.038, \quad d_{18}^{+}=0.046$,

$d_{19}^{+}=0.035, \quad d_{20}^{+}=0.03, \quad d_{21}^{+}=0.034$,

$d_{22}^{+}=0.06, \quad d_{23}^{+}=0.078, \quad d_{24}^{+}=0.067$,

$d_{25}^{+}=0.034, \quad d_{26}^{+}=0.091, \quad d_{27}^{+}=0.065$,

$d_{28}^{+}=0.036, \quad d_{29}^{+}=0.045, \quad d_{30}^{+}=0.074$,

$d_{1}^{-}=0.072, \quad d_{2}^{-}=0.08, \quad d_{3}^{-}=0.089$,

$d_{4}^{-}=0.097, \quad d_{5}^{-}=0.072, \quad d_{6}^{-}=0.083$,

$d_{7}^{-}=0.074, \quad d_{8}^{-}=0.068, \quad d_{9}^{-}=0.055$,

$d_{10}^{-}=0.059, \quad d_{11}^{-}=0.05, \quad d_{12}^{-}=0.025$,

$d_{13}^{-}=0.028, \quad d_{14}^{-}=0.019, \quad d_{15}^{-}=0.043$,

$d_{16}^{-}=0.047, \quad d_{17}^{-}=0.076, \quad d_{18}^{-}=0.068$,

$d_{19}^{-}=0.077, \quad d_{20}^{-}=0.089, \quad d_{21}^{-}=0.079$, 
TABLE 5: Final weights of criteria and subcriteria using FAHP.

\begin{tabular}{|c|c|c|c|c|}
\hline Criteria & Criteria weights & Subcriteria & Subcriteria weights & Local weights \\
\hline \multirow{3}{*}{$\mathrm{C} 1$ : autonomy } & \multirow{3}{*}{0.08} & C11: management style & 0.44 & 0.035 \\
\hline & & C12: having ownership & 0.07 & 0.005 \\
\hline & & C13: awareness of emerging & 0.49 & 0.039 \\
\hline \multirow{2}{*}{ C2: innovativeness } & \multirow{2}{*}{0.33} & C21: technological in. & 0.5 & 0.165 \\
\hline & & C22: product/market in. & 0.5 & 0.165 \\
\hline \multirow{3}{*}{ C3: risk taking } & \multirow{3}{*}{0.1} & C31: venturing into the unknown business & 0.56 & 0.056 \\
\hline & & C32: heavy borrowing & 0.25 & 0.025 \\
\hline & & C33: committing large portions & 0.19 & 0.019 \\
\hline \multirow{4}{*}{ C4: proactiveness } & \multirow{4}{*}{0.29} & C41: being knowledgeable & 0.3 & 0.087 \\
\hline & & C42: developing plans & 0.1 & 0.029 \\
\hline & & C43: commitment to exploiting opportunities & 0.3 & 0.087 \\
\hline & & C44: anticipation of future & 0.3 & 0.087 \\
\hline \multirow{2}{*}{ C5: comp. aggr. } & \multirow{2}{*}{0.2} & C51: intensity of a firm & 0.5 & 0.1 \\
\hline & & C52: adopting unconventional & 0.5 & 0.1 \\
\hline
\end{tabular}

TABLE 6: Linguistic variables for the criteria weights.

\begin{tabular}{lc}
\hline Very low (VL) & 1 \\
Low $(\mathrm{L})$ & 3 \\
Medium $(\mathrm{M})$ & 5 \\
High $(\mathrm{H})$ & 7 \\
Very high $(\mathrm{VH})$ & 9 \\
Intermediate value & $2,4,6,8$ \\
\hline
\end{tabular}

$$
\begin{array}{lll}
d_{22}^{-}=0.053, & d_{23}^{-}=0.037, & d_{24}^{-}=0.048, \\
d_{25}^{-}=0.086, & d_{26}^{-}=0.026, & d_{27}^{-}=0.038, \\
d_{28}^{-}=0.075, & d_{29}^{-}=0.076, & d_{30}^{-}=0.052 .
\end{array}
$$

The closeness coefficients of each alternative were calculated by (11):

$$
\begin{aligned}
& C_{1}^{+}=\frac{0.072}{0.038+0.072}=0.654, \\
& C_{2}^{+}=\frac{0.08}{0.04+0.08}=0.66, \\
& C_{3}^{+}=\frac{0.089}{0.02+0.089}=0.816, \\
& C_{4}^{+}=\frac{0.097}{0.013+0.097}=0.881, \\
& C_{5}^{+}=\frac{0.072}{0.039+0.072}=0.648, \\
& C_{6}^{+}=\frac{0.083}{0.036+0.083}=0.697, \\
& C_{7}^{+}=\frac{0.074}{0.039+0.074}=0.655,
\end{aligned}
$$

$$
\begin{aligned}
& C_{8}^{+}=\frac{0.068}{0.044+0.068}=0.607, \\
& C_{9}^{+}=\frac{0.055}{0.062+0.055}=0.47, \\
& C_{10}^{+}=\frac{0.059}{0.058+0.059}=0.504, \\
& C_{11}^{+}=\frac{0.05}{0.066+0.05}=0.431, \\
& C_{12}^{+}=\frac{0.025}{0.085+0.025}=0.227, \\
& C_{13}^{+}=\frac{0.028}{0.084+0.028}=0.25, \\
& C_{14}^{+}=\frac{0.019}{0.095+0.019}=0.166, \\
& C_{15}^{+}=\frac{0.043}{0.067+0.043}=0.39, \\
& C_{23}^{+}=\frac{0.037}{0.078+0.037}=0.321, \\
& C_{16}^{+}=\frac{0.047}{0.07+0.047}=0.401, \\
& C_{19}^{+}=\frac{0.077}{0.035+0.077}=0.687, \\
& C_{17}^{+}=\frac{0.076}{0.038+0.076}=0.67, \\
& C_{18}^{+}=\frac{0.068}{0.046+0.068}=0.596, \\
& 0.03+0.089
\end{aligned}
$$


TABLE 7: The aggregated EI scores of the firms.

\begin{tabular}{|c|c|c|c|c|c|c|c|c|c|c|c|c|c|c|c|c|c|c|c|c|}
\hline Firm & $\mathrm{C} 1$ & $\mathrm{C} 2$ & C3 & $\mathrm{C} 4$ & C5 & C11 & $\mathrm{C} 12$ & $\mathrm{C} 13$ & C21 & C22 & C31 & C32 & C33 & C41 & C42 & C43 & C44 & C51 & C52 & EI \\
\hline $\mathrm{A} 1$ & 5 & 7 & 5 & 5 & 5 & 3 & 5 & 7 & 7 & 6 & 5 & 1 & 3 & 7 & 3 & 6 & 5 & 6 & 7 & 0.606 \\
\hline A2 & 4 & 8 & 4 & 6 & 5 & 2 & 5 & 6 & 6 & 5 & 4 & 1 & 2 & 8 & 4 & 7 & 5 & 5 & 5 & 0.599 \\
\hline A3 & 5 & 7 & 5 & 6 & 6 & 3 & 4 & 6 & 8 & 7 & 7 & 3 & 4 & 8 & 4 & 7 & 5 & 6 & 6 & 0.662 \\
\hline A4 & 6 & 7 & 5 & 7 & 7 & 4 & 6 & 7 & 8 & 7 & 6 & 2 & 5 & 7 & 5 & 8 & 6 & 7 & 7 & 0.71 \\
\hline A5 & 4 & 7 & 5 & 5 & 6 & 3 & 4 & 6 & 7 & 6 & 5 & 2 & 2 & 6 & 5 & 6 & 4 & 6 & 6 & 0.6 \\
\hline A6 & 5 & 8 & 6 & 6 & 6 & 2 & 3 & 5 & 6 & 5 & 6 & 1 & 3 & 6 & 4 & 5 & 6 & 7 & 5 & 0.625 \\
\hline A7 & 6 & 6 & 4 & 6 & 7 & 4 & 4 & 7 & 6 & 5 & 7 & 2 & 5 & 7 & 4 & 6 & 7 & 6 & 5 & 0.617 \\
\hline A 8 & 7 & 6 & 5 & 6 & 5 & 3 & 6 & 5 & 8 & 5 & 6 & 4 & 3 & 4 & 6 & 5 & 4 & 5 & 4 & 0.576 \\
\hline A9 & 3 & 5 & 5 & 4 & 7 & 6 & 3 & 6 & 5 & 4 & 4 & 4 & 5 & 5 & 3 & 4 & 5 & 6 & 5 & 0.511 \\
\hline A10 & 4 & 6 & 3 & 5 & 5 & 5 & 3 & 4 & 5 & 3 & 4 & 1 & 4 & 5 & 4 & 6 & 5 & 6 & 7 & 0.518 \\
\hline A11 & 5 & 6 & 3 & 3 & 4 & 3 & 2 & 5 & 6 & 5 & 5 & 3 & 2 & 3 & 2 & 4 & 4 & 4 & 4 & 0.457 \\
\hline A12 & 3 & 3 & 5 & 3 & 4 & 2 & 4 & 4 & 5 & 4 & 4 & 3 & 2 & 3 & 4 & 4 & 3 & 2 & 4 & 0.371 \\
\hline A13 & 2 & 3 & 4 & 5 & 3 & 3 & 5 & 4 & 3 & 3 & 3 & 4 & 3 & 4 & 2 & 5 & 2 & 4 & 4 & 0.369 \\
\hline A14 & 1 & 2 & 3 & 4 & 2 & 3 & 4 & 4 & 4 & 3 & 3 & 2 & 3 & 2 & 2 & 4 & 3 & 4 & 3 & 0.308 \\
\hline A15 & 3 & 5 & 4 & 4 & 4 & 4 & 5 & 3 & 6 & 4 & 4 & 5 & 4 & 3 & 3 & 3 & 5 & 5 & 5 & 0.455 \\
\hline A16 & 4 & 5 & 4 & 3 & 2 & 5 & 5 & 5 & 6 & 6 & 5 & 1 & 3 & 4 & 5 & 6 & 6 & 5 & 6 & 0.474 \\
\hline A17 & 4 & 7 & 5 & 6 & 6 & 3 & 4 & 6 & 7 & 5 & 5 & 2 & 2 & 6 & 5 & 6 & 4 & 5 & 6 & 0.61 \\
\hline A18 & 5 & 7 & 5 & 4 & 5 & 3 & 5 & 7 & 6 & 6 & 5 & 1 & 3 & 6 & 3 & 6 & 5 & 6 & 7 & 0.578 \\
\hline A19 & 3 & 7 & 5 & 6 & 5 & 3 & 3 & 6 & 8 & 6 & 7 & 3 & 3 & 8 & 4 & 7 & 4 & 6 & 6 & 0.629 \\
\hline A20 & 5 & 8 & 6 & 5 & 6 & 2 & 2 & 5 & 6 & 7 & 6 & 1 & 3 & 7 & 4 & 5 & 5 & 7 & 5 & 0.627 \\
\hline A21 & 7 & 6 & 4 & 6 & 5 & 4 & 6 & 5 & 8 & 7 & 6 & 5 & 4 & 4 & 6 & 5 & 4 & 5 & 5 & 0.598 \\
\hline A 22 & 7 & 6 & 3 & 4 & 4 & 3 & 2 & 5 & 5 & 5 & 5 & 5 & 2 & 3 & 2 & 4 & 5 & 4 & 5 & 0.484 \\
\hline A23 & 4 & 3 & 4 & 5 & 5 & 3 & 5 & 5 & 3 & 3 & 5 & 4 & 3 & 4 & 3 & 5 & 2 & 4 & 6 & 0.424 \\
\hline A24 & 5 & 5 & 6 & 3 & 4 & 4 & 6 & 3 & 6 & 5 & 4 & 5 & 3 & 4 & 3 & 3 & 5 & 7 & 5 & 0.482 \\
\hline A 25 & 6 & 8 & 5 & 6 & 7 & 3 & 5 & 6 & 7 & 5 & 5 & 2 & 3 & 6 & 5 & 6 & 5 & 5 & 6 & 0.642 \\
\hline A26 & 2 & 2 & 4 & 4 & 3 & 3 & 4 & 5 & 6 & 3 & 3 & 3 & 4 & 2 & 2 & 5 & 3 & 4 & 7 & 0.375 \\
\hline A 27 & 3 & 4 & 5 & 5 & 5 & 3 & 4 & 6 & 5 & 5 & 4 & 3 & 2 & 4 & 4 & 4 & 3 & 2 & 5 & 0.454 \\
\hline A28 & 4 & 7 & 5 & 6 & 5 & 3 & 5 & 5 & 6 & 6 & 5 & 1 & 3 & 8 & 4 & 8 & 5 & 5 & 7 & 0.614 \\
\hline A29 & 5 & 7 & 4 & 5 & 7 & 4 & 5 & 7 & 6 & 4 & 7 & 1 & 5 & 7 & 5 & 6 & 7 & 7 & 5 & 0.612 \\
\hline A30 & 3 & 4 & 6 & 3 & 7 & 6 & 6 & 5 & 5 & 3 & 4 & 5 & 5 & 6 & 3 & 4 & 6 & 6 & 7 & 0.492 \\
\hline$W$ & 0.08 & 0.33 & 0.1 & 0.29 & 0.2 & 0.035 & 0.005 & 0.039 & 0.165 & 0.165 & 0.056 & 0.025 & 0.019 & 0.087 & 0.029 & 0.087 & 0.087 & 0.1 & 0.1 & \\
\hline
\end{tabular}

TABLE 8: The values of $S$ and $R$ for all firms.

\begin{tabular}{|c|c|c|c|c|c|c|c|}
\hline Firm & $S$ & $R$ & Firm & $S$ & $R$ & & \\
\hline $\mathrm{A} 1$ & 0.63 & 0.145 & A16 & 1.13 & 0.29 & \multirow{15}{*}{$\begin{array}{l}S_{j}^{*}=0.39 \\
S_{j}^{-}=1.78\end{array}$} & \multirow{15}{*}{$\begin{array}{l}R_{j}^{*}=0.072 \\
R_{j}^{-}=0.33\end{array}$} \\
\hline A 2 & 0.656 & 0.08 & A17 & 0.647 & 0.082 & & \\
\hline A3 & 0.39 & 0.072 & A18 & 0.75 & 0.217 & & \\
\hline A4 & 0.477 & 0.29 & A19 & 0.526 & 0.082 & & \\
\hline A5 & 0.659 & 0.145 & A20 & 0.634 & 0.145 & & \\
\hline A6 & 0.649 & 0.082 & A21 & 0.635 & 0.109 & & \\
\hline A7 & 0.577 & 0.109 & A22 & 1.129 & 0.217 & & \\
\hline A8 & 0.73 & 0.11 & A23 & 1.344 & 0.274 & & \\
\hline A9 & 1.17 & 0.217 & A 24 & 1.109 & 0.29 & & \\
\hline A10 & 0.998 & 0.165 & A25 & 0.496 & 0.082 & & \\
\hline A11 & 1.25 & 0.29 & A26 & 1.506 & 0.33 & & \\
\hline A12 & 1.53 & 0.29 & A27 & 1.181 & 0.219 & & \\
\hline A13 & 1.53 & 0.274 & A28 & 0.549 & 0.082 & & \\
\hline A14 & 1.78 & 0.33 & A29 & 0.627 & 0.145 & & \\
\hline A15 & 1.219 & 0.217 & A30 & 1.188 & 0.29 & & \\
\hline
\end{tabular}


TABLE 9: The ranking of the firms by $S, R$, and $Q$ in an ascending order.

\begin{tabular}{|c|c|c|c|c|c|}
\hline \multicolumn{2}{|c|}{$Q$} & \multicolumn{2}{|c|}{$R$} & \multicolumn{2}{|c|}{$S$} \\
\hline A3 & 0.0 & A3 & 0.072 & A3 & 0.39 \\
\hline A25 & 0.057 & A 25 & 0.082 & A4 & 0.477 \\
\hline A19 & 0.063 & A19 & 0.082 & A25 & 0.496 \\
\hline A28 & 0.076 & A28 & 0.082 & A19 & 0.526 \\
\hline $\mathrm{A} 2$ & 0.11 & $\mathrm{~A} 2$ & 0.082 & A28 & 0.549 \\
\hline A17 & 0.111 & A17 & 0.082 & A7 & 0.577 \\
\hline A6 & 0.112 & A6 & 0.082 & A29 & 0.627 \\
\hline A7 & 0.138 & A7 & 0.109 & $\mathrm{~A} 1$ & 0.63 \\
\hline A21 & 0.159 & A21 & 0.109 & A 20 & 0.634 \\
\hline A8 & 0.195 & A8 & 0.11 & A21 & 0.635 \\
\hline A29 & 0.226 & A29 & 0.145 & A17 & 0.647 \\
\hline $\mathrm{A} 1$ & 0.227 & A5 & 0.145 & A6 & 0.649 \\
\hline A20 & 0.228 & A20 & 0.145 & $\mathrm{~A} 2$ & 0.656 \\
\hline A5 & 0.237 & $\mathrm{~A} 1$ & 0.145 & A5 & 0.659 \\
\hline A10 & 0.398 & $\mathrm{~A} 10$ & 0.165 & A8 & 0.73 \\
\hline A18 & 0.41 & A18 & 0.217 & A18 & 0.75 \\
\hline $\mathrm{A} 4$ & 0.453 & A9 & 0.217 & A10 & 0.998 \\
\hline A 22 & 0.549 & A 22 & 0.217 & A24 & 1.109 \\
\hline A9 & 0.561 & A15 & 0.217 & A 22 & 1.129 \\
\hline A27 & 0.568 & A27 & 0.219 & A16 & 1.13 \\
\hline A15 & 0.579 & A13 & 0.274 & A9 & 1.17 \\
\hline A24 & 0.68 & A23 & 0.274 & A27 & 1.181 \\
\hline A16 & 0.688 & $\mathrm{~A} 4$ & 0.29 & A 30 & 1.188 \\
\hline A30 & 0.709 & $\mathrm{~A} 30$ & 0.29 & A15 & 1.219 \\
\hline A11 & 0.731 & A16 & 0.29 & A11 & 1.25 \\
\hline A23 & 0.734 & A24 & 0.29 & A23 & 1.344 \\
\hline A13 & 0.801 & A11 & 0.29 & A26 & 1.506 \\
\hline A12 & 0.832 & A12 & 0.29 & A13 & 1.53 \\
\hline A26 & 0.901 & A26 & 0.33 & A12 & 1.53 \\
\hline A14 & 1 & A14 & 0.33 & A14 & 1.78 \\
\hline
\end{tabular}

$$
\begin{aligned}
& C_{24}^{+}=\frac{0.048}{0.067+0.048}=0.417 \\
& C_{25}^{+}=\frac{0.086}{0.034+0.086}=0.716 \\
& C_{26}^{+}=\frac{0.026}{0.091+0.026}=0.222 \\
& C_{27}^{+}=\frac{0.038}{0.065+0.038}=0.368 \\
& C_{28}^{+}=\frac{0.075}{0.036+0.075}=0.675 \\
& C_{29}^{+}=\frac{0.038}{0.065+0.038}=0.368 \\
& C_{30}^{+}=\frac{0.052}{0.074+0.052}=0.412
\end{aligned}
$$

\begin{tabular}{|c|c|c|c|c|}
\hline Firms & VIKOR $_{Q}$ & VIKOR $_{R}$ & VIKOR $_{S}$ & TOPSIS \\
\hline $\mathrm{A} 1$ & 12 & 14 & 8 & 12 \\
\hline A2 & 5 & 5 & 13 & 10 \\
\hline A3 & 1 & 1 & 1 & 2 \\
\hline A4 & 17 & 23 & 2 & 1 \\
\hline A5 & 14 & 12 & 14 & 13 \\
\hline A6 & 7 & 7 & 12 & 6 \\
\hline A7 & 8 & 8 & 6 & 11 \\
\hline A8 & 10 & 10 & 15 & 14 \\
\hline A9 & 19 & 17 & 21 & 17 \\
\hline A10 & 15 & 15 & 17 & 16 \\
\hline A11 & 25 & 27 & 25 & 19 \\
\hline A12 & 28 & 28 & 29 & 28 \\
\hline A13 & 27 & 21 & 28 & 27 \\
\hline A14 & 30 & 30 & 30 & 30 \\
\hline A15 & 21 & 19 & 24 & 23 \\
\hline A16 & 23 & 25 & 20 & 22 \\
\hline A17 & 6 & 6 & 11 & 9 \\
\hline A18 & 16 & 16 & 16 & 15 \\
\hline A19 & 3 & 3 & 4 & 7 \\
\hline A 20 & 13 & 13 & 9 & 3 \\
\hline A21 & 9 & 9 & 10 & 5 \\
\hline A22 & 18 & 18 & 19 & 18 \\
\hline A23 & 26 & 22 & 26 & 26 \\
\hline A24 & 22 & 26 & 18 & 20 \\
\hline A25 & 2 & 2 & 3 & 4 \\
\hline A26 & 29 & 29 & 27 & 29 \\
\hline A27 & 20 & 20 & 22 & 24 \\
\hline A28 & 4 & 4 & 5 & 8 \\
\hline A29 & 11 & 11 & 7 & 25 \\
\hline A30 & 24 & 24 & 23 & 21 \\
\hline
\end{tabular}

TABLE 10: Comparison of VIKOR and TOPSIS.

Comparing $C C_{i}$ values, the ranking of main criteria was determined as follows:

$$
\begin{aligned}
C_{4} & >C_{3}>C_{20}>C_{25}>C_{21}>C_{6}>C_{19}>C_{28}>C_{17} \\
& >C_{2}>C_{7}>C_{1}>C_{5}>C_{8}>C_{18}>C_{10} \\
& >C_{9}>C_{22}>C_{11}>C_{24}>C_{30}>C_{16}>C_{15} \\
& >C_{27}>C_{29}>C_{23}>C_{13}>C_{12}>C_{26}>C_{14} .
\end{aligned}
$$

The summary of ranking based on VIKOR and TOPSIS methods is shown in Table 10.

\section{Results and Discussions}

This paper applied an approach based on the FAHP-VIKOR and FAHP-TOPSIS techniques for evaluating and prioritizing the CSFs of EI among the SMEs. In this research FAHP is used for finding weights of criteria and subcriteria. Then two wellknown MCDM techniques for ranking were used together to see the differences of two methods that applied over the same data. Based on obtaining weight by FAHP, innovativeness 
with 0.33 is placed in first priority, proactiveness with 0.29 in second place, competitive aggressiveness with 0.2 in third place, risk taking with 0.1 in fourth place, and autonomy with 0.08 in fifth place with lower importance. In innovativeness group, technological and product/market innovations earned same weight with 0.5 . In proactiveness group, being knowledgeable about current and future customers' preferences, commitment to exploiting opportunities and anticipation of future demand are placed in first priority with 0.087 and developing plans in the second rank with 0.029. In competitive aggressiveness groups, adopting unconventional tactics to challenge industry leaders and intensity of a firm's effort to outperform industry rivals obtained the same weight 0.1. In risk taking group, venturing into the unknown business received the first rank with 0.056 , heavy borrowing got the second rank with 0.026 , and committing large portions of corporate assets in uncertain environments got the third rank with 0.019. In autonomy group, awareness of emerging technologies with 0.039 received the first rank, management style with 0.035 was in the second, and having ownership got the third rank with 0.005 .

The final aggregated EI score of firm $m, \mathrm{EI}_{m}$, is calculated as $\mathrm{EI}_{k}=\sum_{i=1}^{n} w_{i} \varphi_{i m}, m=1, \ldots M$, where $w_{i}$ is the local weight of subcriterion $i ; \varphi_{i m}$ is the assigned score to firm $m$ with respect to subcriterion $i ; n$ is the number of subcriteria; and $M$ is the number of firms. Table 7 shows the final summed scores of the firm. In the last column of Table 7 , the relative level of entrepreneurship of the various firms can be found. For example, firm A4, with EI $=0.71$, reflected the most entrepreneurial firm, while firm A14, with EI $=0.308$, reflects the least entrepreneurial firm.

As depicted in Table 10, three indicators $(Q, R, S)$ in VIKOR method were used to compare the results with the TOPSIS. Comparing TOPSIS with VIKOR (Q) values showed that only seven items are compatible. The VIKOR and TOPSIS use different aggregation functions and different normalization methods. The VIKOR method introduces the ranking index based on the particular measure of "closeness" to the ideal solution. In contrast, the basic principle of the TOPSIS method is that the chosen alternative should have the "shortest distance" from the positive ideal solution (PIS) and the "farthest distance" from negative ideal solution (NIS) but it does not consider the relative importance of these distances. These two MCDM methods use different kinds of normalization to eliminate the units of criterion functions: the VIKOR method uses linear normalization, and the TOPSIS method uses vector normalization.

\section{Conclusion}

Previous researches focused on three dimensions of EO (innovativeness, risk taking, and proactiveness); however, to the best of our knowledge, there is no more research that has applied the Lumpkin and Dess five dimensions of entrepreneurship measurement using MCDM techniques. Also, we developed subcriteria for the above-mentioned dimensions of the evaluation. Thus, there is a need for a more structured approach to evaluations and decision

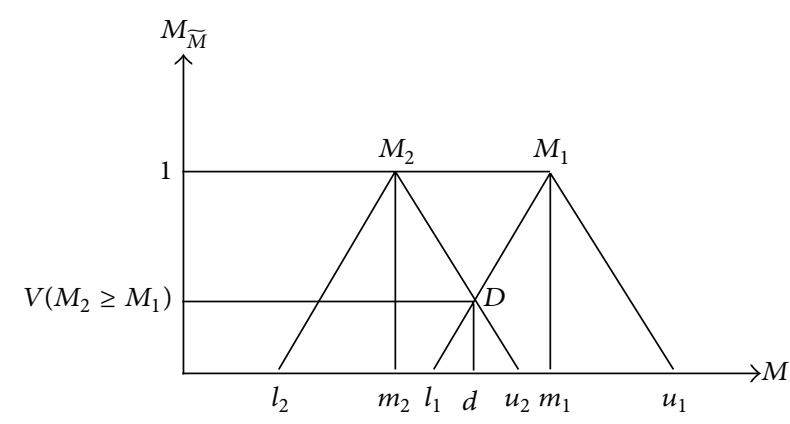

FIgURE 3: The intersection between $M_{1}$ and $M_{2}$.

making in the field of EI. This research has been done in the manufacturing sector located in Skudai area in Malaysia and only 30 companies have been investigated. For collecting comprehensive data about the situation of entrepreneurial intensity among the Malaysian firms, it would be better to implement in whole country and particularly in the same sector. The proposed criteria of this research could be also extended to the service sector with slight modification based on their needs. In future research, a comparative study using other MCDM methods like PROMETHEE, ELECTRE, and DEMATEL can be applied to assess the EI of firms in fuzzy environment.

\section{Appendix}

Let $X\left\{x_{1}, x_{2}, \ldots, x_{n}\right\}$ be an object set, and let $U\left\{u_{1}, u_{2}, \ldots, u_{n}\right\}$ be a goal set. According to the method of Chang (1992), each object is taken and extent analysis for each goal $g_{i}$ is performed, respectively. Therefore, $m$ extent analysis values for each object can be obtained, with the following signs

$$
M_{g_{i}}^{1}, M_{g_{i}}^{2}, \ldots, M_{g_{i}}^{m}, \quad i=1,2, \ldots, n,
$$

where all the $M_{g_{i}}^{j}(j=1,2, \ldots, m)$ are TFNs. The steps of Chang's extent analysis can be given as in the following.

Step 16. The value of fuzzy synthetic extent with respect to the $i$ th object is defined as

$$
S_{i}=\sum_{j=1}^{m} M_{g i}^{j} \otimes\left[\sum_{i=1}^{n} \sum_{j=1}^{m} M_{g i}^{j}\right]^{-1} .
$$

To obtain $\left[\sum_{i=1}^{n} \sum_{j=1}^{m} M_{g_{i}}^{j}\right]^{-1}$, perform the fuzzy addition operation of $m$ extent analysis values for a particular matrix such that

$$
\begin{gathered}
\sum_{j=1}^{m} M_{g i}^{j}=\left(\sum_{j=1}^{m} l_{i} \sum_{j=1}^{m} m_{i} \sum_{j=1}^{m} u_{i}\right), \\
\sum_{i=1}^{n} \sum_{j=1}^{m} M_{g i}^{j}=\left(\sum_{j=1}^{n} l_{i} \sum_{j=1}^{n} m_{i} \sum_{j=1}^{n} u_{i}\right),
\end{gathered}
$$




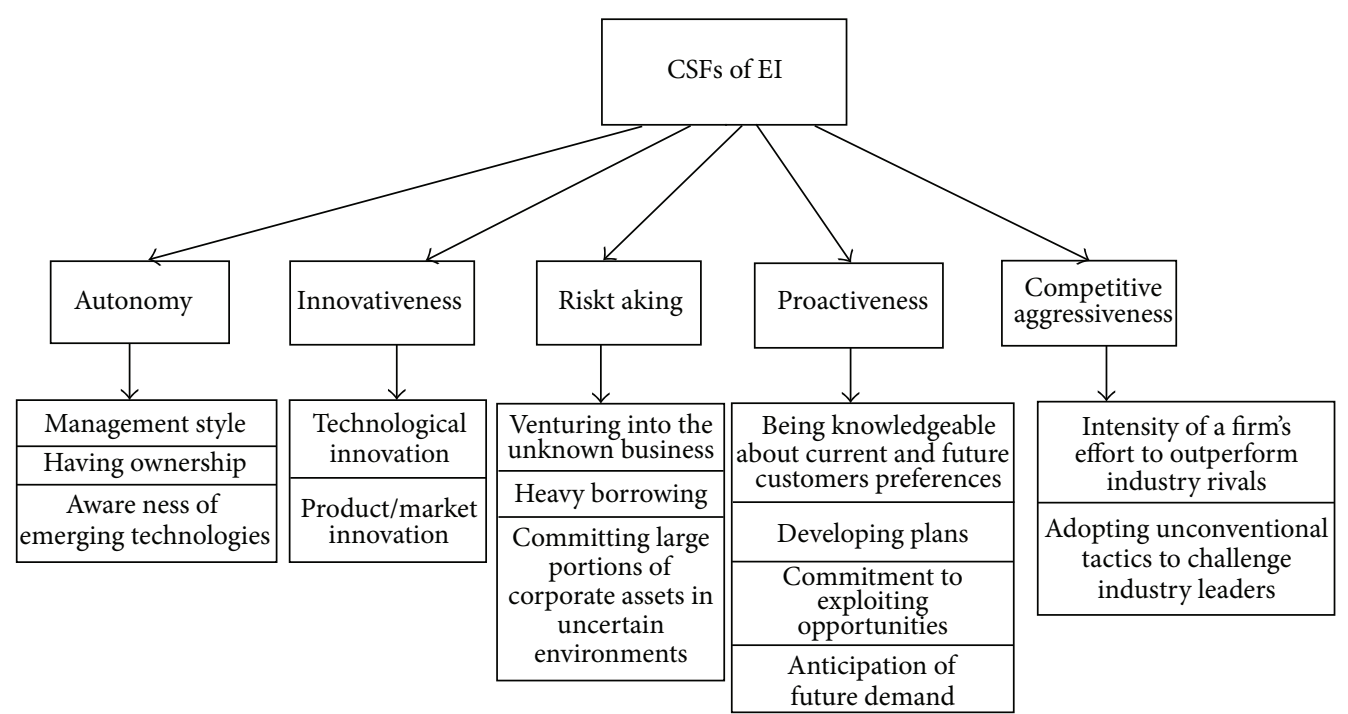

FIgURE 4: Hierarchy of the problem.

and then compute the inverse of the vector in (A.4) such that

$$
\left[\sum_{i=1}^{n} \sum_{j=1}^{m} M_{g_{i}}^{j}\right]^{-1}=\left(\frac{1}{\sum_{i=1}^{n} u_{i}}, \frac{1}{\sum_{i=1}^{n} m_{i}}, \frac{1}{\sum_{i=1}^{n} l_{i}}\right) .
$$

Step 17. The degree of possibility of $M_{2}=\left(l_{2}, m_{2} u_{2}\right) \geq M_{1}=$ $\left(l_{2}, m_{2} u_{2}\right)$ is defined as

$$
V\left(M_{2} \geq M_{1}\right)={ }_{y \geq x}^{\text {SUP }}\left\lfloor\min \left(\mu_{M_{1}}(x), \mu_{M_{2}}(y)\right)\right\rfloor,
$$

which can be equivalently expressed as follows:

$$
\begin{aligned}
& V\left(M_{2} \geq M_{1}\right)= \operatorname{hgt}\left(M_{1} \cap M_{2}\right)=\mu_{M_{2}}(d) \\
&= \begin{cases}1 & \text { if } m_{2} \geq m_{1} \\
0 & \text { if } l_{1} \geq u_{2} \\
\frac{l_{1}-u_{2}}{\left(m_{2}-u_{2}\right)-\left(m_{1}-l_{1}\right)} & \text { otherwise, }\end{cases}
\end{aligned}
$$

where $d$ is the ordinate of the highest intersection point $D$ between $\mu_{M_{1}}$ and $\mu_{M_{2}}$ (see Figure 3 ).

To compare $M_{1}$ and $M_{2}$, we need both of the values of $V\left(M_{1} \geq M_{2}\right)$ and $V\left(M_{2} \geq M_{1}\right)$.

Step 18. The degree possibility for a convex fuzzy number to be greater than $k$ convex fuzzy numbers $M_{i}(i=1,2, \ldots, k)$ can be defined by

$$
\begin{aligned}
V(M & \left.\geq M_{1}, M_{2}, \ldots, M_{K}\right) \\
& \left.=V\left[\begin{array}{c}
\left(M \geq M_{1}\right) \\
\text { and }\left(M \geq M_{2}\right) \\
\left(M \geq M_{K}\right)
\end{array}\right) \text { and } \ldots \text { and }\right] \\
& =\min V\left(M \geq M_{i}\right), \quad i=1,2,3, \ldots, k .
\end{aligned}
$$

Assume that

$$
d^{\prime}\left(A_{i}\right)=\min V\left(S_{i} \geq S_{k}\right)
$$

for $k=1,2, \ldots n, k \neq i$. Then the weight vector is given by

$$
W^{\prime}=\left(d^{\prime}\left(A_{1}\right), d^{\prime}\left(A_{2}\right), \ldots, d^{\prime}\left(A_{n}\right)\right)^{T},
$$

where $A_{i}(i=1,2, \ldots, n)$ are $n$ elements.

Step 19. Via normalization, the normalized weight vectors are given by

$$
W=\left(d\left(A_{1}\right), d\left(A_{1}\right), \ldots, d\left(A_{1}\right)\right)^{T},
$$

where $W$ is a nonfuzzy number.

\section{Conflict of Interests}

The authors declare that there is no conflict of interests regarding the publication of this paper.

\section{Acknowledgments}

This research is conducted under the Postdoctoral Program of Universiti Teknologi Malaysia (UTM). The authors are grateful to the Research Management Centre (RMC) for the generous support with this research.

\section{References}

[1] W. Tsai and H. Kuo, "Entrepreneurship policy evaluation and decision analysis for SMEs," Expert Systems with Applications, vol. 38, no. 7, pp. 8343-8351, 2011.

[2] R. G. Javalgi and P. R. Todd, "Entrepreneurial orientation, management commitment, and human capital: the internationalization of SMEs in India," Journal of Business Research, vol. 64, no. 9, pp. 1004-1010, 2011. 
[3] B. Nooteboom, "Innovation and diffusion in small firms: theory and evidence," Small Business Economics, vol. 6, no. 5, pp. 327347, 1994

[4] N. O. Ndubisi, O. K. Gupta, and G. C. Ndubisi, "The moguls' model of computing: integrating the moderating impact of users' persona into the technology acceptance model," Journal of Global Information Technology Management, vol. 8, no. 1, pp. 27-47, 2005.

[5] N. O. Ndubisi and K. Iftikhar, "Relationship between entrepreneurship, innovation and performance: comparing small and medium-size enterprises," Journal of Research in Marketing and Entrepreneurship, vol. 14, no. 2, pp. 214-236, 2012.

[6] A. Ardichvili, R. Cardozo, and S. Ray, "A theory of entrepreneurial opportunity identification and development," Journal of Business Venturing, vol. 18, no. 1, pp. 105-123, 2003.

[7] C. Korunka, H. Frank, M. Lueger, and J. Mugler, "The entrepreneurial personality in the context of resources, environment and the startup process-a configurational approach," Entrepreneurship Theory and Practice, vol. 28, no. 1, pp. 23-42, 2003.

[8] Y. R. Choi and D. A. Shepherd, "Entrepreneurs' decisions to exploit opportunities," Journal of Management, vol. 30, no. 3, pp. 377-395, 2004.

[9] B. Clarysse and N. Moray, "A process study of entrepreneurial team formation: the case of a research-based spin-off," Journal of Business Venturing, vol. 19, no. 1, pp. 55-79, 2004.

[10] S. Shane and D. Cable, "Network ties, reputation, and the financing of new ventures," Management Science, vol. 48, no. 3, pp. 364-381, 2002.

[11] D. R. DeTienne, "Entrepreneurial exit as a critical component of the entrepreneurial process: theoretical development," Journal of Business Venturing, vol. 25, no. 2, pp. 203-215, 2010.

[12] N. E. Coviello, P. P. McDougall, and B. M. Oviatt, "The emergence, advance and future of international entrepreneurship research-an introduction to the special forum," Journal of Business Venturing, vol. 26, no. 6, pp. 625-631, 2011.

[13] A. R. Reuber and E. Fischer, "International entrepreneurship in internet-enabled markets," Journal of Business Venturing, vol. 26, no. 6, pp. 660-679, 2011.

[14] J. C. Carr and J. M. Sequeira, "Prior family business exposure as intergenerational influence and entrepreneurial intent: a Theory of Planned Behavior approach," Journal of Business Research, vol. 60, no. 10, pp. 1090-1098, 2007.

[15] T. Kautonen, E. T. Tornikoski, and E. Kibler, "Entrepreneurial intentions in the third age: the impact of perceived age norms," Small Business Economics, vol. 37, no. 2, pp. 219-234, 2011.

[16] T. Kautonen, S. Luoto, and E. T. Tornikoski, "Influence of work history on entrepreneurial intentions in "prime age" and "third age": a preliminary study," International Small Business Journal, vol. 28, no. 6, pp. 583-601, 2010.

[17] E. J. Schwarz, M. A. Wdowiak, D. A. Almer-Jarz, and R. J. Breitenecker, "The effects of attitudes and perceived environment conditions on students' entrepreneurial intent: an Austrian perspective," Education and Training, vol. 51, no. 4, pp. 272-291, 2009.

[18] W. L. Koe, J. R. Sa’ari, I. A. Majid, and K. Ismail, "Determinants of entrepreneurial intention among millennial generation," Procedia-Social and Behavioral Sciences, vol. 40, pp. 197-208, 2012.

[19] G. H. Tzeng and J. J. Huang, Multiple Attribute Decision Making: Methods and Applications, Taylor Francis/CRC Press, Boca Raton, Fla, USA, 2011.
[20] C. T. Lin and C. S. Wu, "Selecting a marketing strategy for private hotels in Taiwan using the analytic hierarchy process," The Service Industries Journal, vol. 28, no. 8, pp. 1077-1091, 2008.

[21] J. Y. Han, Y. B. Yang, and Y. H. Zhao, "Evaluation of entrepreneurial environment based on fuzzy comprehensive evaluation method," in Proceedings of the International Conference on Machine Learning and Cybernetics (ICMLC '12), pp. 305-309, Xian, China, July 2012.

[22] Z. Ni-Di and L. Yi, "Comprehensive evaluation of entrepreneurial capacity of college students," in Proceedings of the 2nd IEEE International Conference on Information Management and Engineering (ICIME '10), pp. 490-494, Chengdu, China, April 2010.

[23] J. Rezaei, R. Ortt, and V. Scholten, "Measuring entrepreneurship: expert-based vs. data-based methodologies," Expert Systems with Applications, vol. 39, no. 4, pp. 4063-4074, 2012.

[24] J. Rezaei, R. Ortt, and V. Scholten, "An improved fuzzy preference programming to evaluate entrepreneurship orientation," Applied Soft Computing Journal, vol. 13, no. 5, pp. 2749-2758, 2013.

[25] I. Y. Lu, C. B. Chen, and C. H. Wang, "Fuzzy multiattribute analysis for evaluating firm technological innovation capability," International Journal of Technology Management, vol. 40, no. 1-3, pp. 114-130, 2007.

[26] Z. Chen, H. Li, S. C. W. Kong, and W. Xu, "An analytic knowledge network process for construction entrepreneurship education," Journal of Management Development, vol. 25, no. 1, pp. 11-27, 2006.

[27] V. Čančer and J. Knez-Riedl, "Why and how to evaluate the creditworthiness of SMEs' business partners," International Small Business Journal, vol. 23, no. 2, pp. 143-162, 2005.

[28] L. A. Stevenson and A. Lundstrom, "Entrepreneurship policy for the future: best practice components," in Proceedings of the 46th World Conference of the International Council for Small Business, Taipei, Taiwan, June 2001.

[29] J. G. Covin and D. P. Slevin, "A conceptual model of entrepreneurship as firm behavior," Entrepreneurship Theory and Practice, vol. 16, pp. 7-25, 1991.

[30] D. L. Sexton and M. H. Morris, "The concept of entrepreneurial intensity: implications for company performance," Journal of Business Research, vol. 36, no. 1, pp. 5-13, 1996.

[31] D. T. Smart and J. S. Conant, "Entrepreneurial orientation, distinctive marketing competencies and organization performance," Journal of Applied Business Research, vol. 10, no. 3, pp. 28-38, 1994.

[32] J. Wiklund, "The sustainability of the entrepreneurial orientationperformance relationship," Entrepreneurship Theory and Practice, vol. 24, pp. 37-48, 1999.

[33] J. Wiklund and D. Shepherd, "Entrepreneurial orientation and small business performance: a configurational approach," Journal of Business Venturing, vol. 20, no. 1, pp. 71-91, 2005.

[34] S. A. Zahra and J. G. Covin, "Contextual influences on the corporate entrepreneurship-performance relationship: a longitudinal analysis," Journal of Business Venturing, vol. 10, no. 1, pp. 43-58, 1995.

[35] H. T. Keh, T. T. M. Nguyen, and H. P. Ng, "The effects of entrepreneurial orientation and marketing information on the performance of SMEs," Journal of Business Venturing, vol. 22, no. 4, pp. 592-611, 2007.

[36] J. G. Covin and G. T. Lumpkin, "Entrepreneurial orientation theory and research: reflections on a needed construct," 
Entrepreneurship: Theory and Practice, vol. 35, no. 5, pp. 855872, 2011.

[37] J. G. Covin and M. P. Miles, "Corporate entrepreneurship and the pursuit of competitive advantage," Entrepreneurship Theory and Practice, vol. 23, pp. 47-63, 1999.

[38] M. H. Morris and D. F. Kuratko, Corporate Entrepreneurship, Harcourt College, Orlando, Fla, USA, 2002.

[39] B. R. Barringer and R. D. Ireland, Entrepreneurship, Successfully Launching New Ventures, Pearson Prentice Hall, Upper Saddle River, NJ, USA, 2nd edition, 2008.

[40] H. Stevenson, M. Roberts, and H. Grousback, New Business Ventures and the Entrepreneur, Irwin, Homewood, Ill, USA, 1989.

[41] D. Miller, "The correlates of entrepreneurship in three types of firms," Management Science, vol. 29, no. 7, pp. 770-791, 1983.

[42] B. Antoncic and R. D. Hisrich, "Intrapreneurship: construct refinement and cross-cultural validation," Journal of Business Venturing, vol. 16, no. 5, pp. 495-527, 2001.

[43] G. T. Lumpkin and G. G. Dess, "Clarifying the entrepreneurial orientation construct and linking it to performance," Academy of Management Review, vol. 21, no. 1, pp. 135-172, 1996.

[44] Z. Yang, R. Li-Hua, X. Zhang, and Y. Wang, "Corporate entrepreneurship and market performance: an empirical study in China," Journal of Technology Management in China, vol. 2, no. 2, pp. 154-162, 2007.

[45] S. Kraus, "The role of entrepreneurial orientation in service firms: empirical evidence from Austria," The Service Industries Journal, vol. 33, no. 5, pp. 427-444, 2013.

[46] J. P. C. Rigtering, S. Kraus, F. Eggers, and S. H. Jensen, "A comparative analysis of the entrepreneurial orientation/growth relationship in service firms and manufacturing firms," The Service Industries Journal, vol. 34, no. 4, pp. 275-294, 2014.

[47] R. Scheepers, J. Hough, and J. Bloom, "Entrepreneurial intensity: a comparative analysis of established companies in South Africa," South African Journal of Economic and Management Sciences, vol. 10, no. 2, pp. 238-255, 2007.

[48] P. Erasmus and R. Scheepers, "The relationship between entrepreneurial intensity and shareholder value creation," Managing Global Transitions, vol. 6, no. 3, pp. 229-256, 2008.

[49] L. Lee, P. K. Wong, M. D. Foo, and A. Leung, "Entrepreneurial intentions: the influence of organizational and individual factors," Journal of Business Venturing, vol. 26, no. 1, pp. 124-136, 2011.

[50] M. S. Cardon, D. A. Gregoire, C. E. Stevens, and P. C. Patel, "Measuring entrepreneurial passion: conceptual foundations and scale validation," Journal of Business Venturing, vol. 28, no. 3, pp. 373-396, 2013.

[51] M. H. Morris, Entrepreneurial Intensity: Sustainable Advantages for Individuals, Organisations and Societies, Quorum, Westport, Conn, USA, 1998.

[52] A. Rauch, J. Wiklund, G. T. Lumpkin, and M. Freese, "Entrepreneurial orientation and business performance: an assessment of past research and suggestions for the future," Entrepreneurship: Theory and Practice, vol. 33, no. 3, pp. 761-787, 2009.

[53] G. George, D.R. Wood Jr., and R. Khan, "Networking strategy of boards: Implications for small and medium-sized enterprises," Entrepreneurship and Regional Development, vol. 13, no. 3, pp. 269-285, 2001.

[54] J. G. Covin and D. P. Slevin, "New venture strategic posture, structure, and performance: an industry life cycle analysis," Journal of Business Venturing, vol. 5, no. 2, pp. 123-135, 1990.
[55] J. G. Covin, D. P. Slevin, and L. R. Schultz, "Implementing strategic missions: effective strategic, structural, and tactic choices," Journal of Management Studies, vol. 31, no. 4, pp. 481503, 1994.

[56] S. F. Slater and J. C. Narver, "The positive effect of a market orientation on business profitability: a balanced replication," Journal of Business Research, vol. 48, no. 1, pp. 69-73, 2000.

[57] J. Wiklund and D. Shepherd, "Knowledge-base resources, entrepreneurial orientation, and the performance of small and medium-sized businesses," Strategic Management Journal, vol. 24, no. 12, pp. 1307-1314, 2003.

[58] J. Soininen, K. Puumalainen, H. Sjögrén, and P. Syrjä, “The impact of global economic crisis on SMEs: does entrepreneurial orientation matter?" Management Research Review, vol. 35, no. 10, pp. 927-944, 2012.

[59] T. L. Saaty, The Analytic Hierarchy Process, McGraw-Hill, New York, NY, USA, 1980.

[60] C. Yang and B. Chen, "Key quality performance evaluation using fuzzy AHP," Journal of the Chinese Institute of Industrial Engineers, vol. 21, no. 6, pp. 543-550, 2004.

[61] L. A. Zadeh, "Fuzzy sets," Information and Computation, vol. 8, no. 3, pp. 338-353, 1965.

[62] C. C. Ragin, Fuzzy-Set Social Science, The University of Chicago Press, London, UK, 2000.

[63] J. J. Buckley, "Fuzzy hierarchical analysis," Fuzzy Sets and Systems, vol. 17, no. 3, pp. 233-247, 1985.

[64] D. Y. Chang, "Applications of the extent analysis method on fuzzy AHP," European Journal of Operational Research, vol. 95, no. 3, pp. 649-655, 1996.

[65] C. H. Cheng, "Evaluating naval tactical missile systems by fuzzy AHP based on the grade value of membership function," European Journal of Operational Research, vol. 96, no. 2, pp. 343-350, 1997.

[66] H. Deng, "Multicriteria analysis with fuzzy pairwise comparison," International Journal of Approximate Reasoning, vol. 21, no. 3, pp. 215-231, 1999.

[67] L. C. Leung and D. Cao, "On consistency and ranking of alternatives in fuzzy AHP," European Journal of Operational Research, vol. 124, no. 1, pp. 102-113, 2000.

[68] L. Mikhailov, "A fuzzy approach to deriving priorities from interval pairwise comparison judgements," European Journal of Operational Research, vol. 159, no. 3, pp. 687-704, 2004.

[69] P. J. M. van Laarhoven and W. Pedrycz, "A fuzzy extension of Saaty's priority theory," Fuzzy Sets and Systems, vol. 11, no. 1-3, pp. 229-241, 1983.

[70] S. Opricovic, Multicriteria Optimization of Civil Engineering Systems, Faculty of Civil Engineering, Belgrade, Serbia, 1998.

[71] S. Opricovic and G. Tzeng, "Multicriteria planning of postearthquake sustainable reconstruction," Computer-Aided Civil and Infrastructure Engineering, vol. 17, no. 3, pp. 211-220, 2002.

[72] S. Opricovic and G. H. Tzeng, "Compromise solution by MCDM methods: a comparative analysis of VIKOR and TOPSIS," European Journal of Operational Research, vol. 156, no. 2, pp. 445-455, 2004.

[73] S. Opricovic and G. Tzeng, "Extended VIKOR method in comparison with outranking methods," European Journal of Operational Research, vol. 178, no. 2, pp. 514-529, 2007.

[74] G. Tzeng, M. Teng, J. Chen, and S. Opricovic, "Multicriteria selection for a restaurant location in Taipei," International Journal of Hospitality Management, vol. 21, no. 2, pp. 171-187, 2002. 
[75] G. Tzeng, C. Lin, and S. Opricovic, "Multi-criteria analysis of alternative-fuel buses for public transportation," Energy Policy, vol. 33, no. 11, pp. 1373-1383, 2005.

[76] P. L. Yu, "A class of solutions for group decision problems," Management Science, vol. 19, no. 8, pp. 936-946, 1973.

[77] M. Zeleny, Multiple Criteria Decision Making, McGraw-Hill, New York, NY, USA, 1982.

[78] J. H. Park, H. J. Cho, and Y. C. Kwun, "Extension of the VIKOR method for group decision making with intervalvalued intuitionistic fuzzy information," Fuzzy Optimization and Decision Making, vol. 10, no. 3, pp. 233-253, 2011.

[79] A. Sanayei, S. F. Mousavi, and A. Yazdankhah, "Group decision making process for supplier selection with VIKOR under fuzzy environment," Expert Systems with Applications, vol. 37, no. 1, pp. 24-30, 2010.

[80] C. L. Hwang and K. Yoon, Multiple Attribute Decision Making Methods and Application, Springer, New York, NY, USA, 1981.

[81] Z. M. Zain, A. M. Akram, and E. K. Ghani, "Entrepreneurship intention among Malaysian business students," Canadian Social Science, vol. 6, no. 3, pp. 34-44, 2010.

[82] Economic Planning Unit and Prime Minister's Department, Eighth Malaysia Plan, 2001-2005, Government Printers, Kuala Lumpur, Malaysia, 2001.

[83] M. Ariff and S. Y. Abu Bakar, "Strengthening entrepreneurship in Malaysia," 2005, http://www.mansfieldfdn.org/backup/programs/program_pdfs/ent_malaysia.pdf.

[84] FMM Directory, Malaysian Industries, vol. 44th, 2013. 


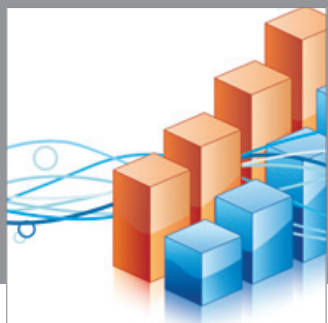

Advances in

Operations Research

mansans

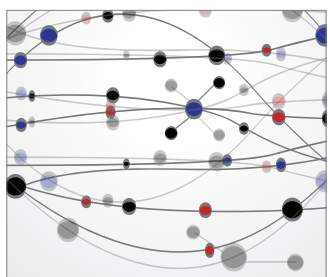

The Scientific World Journal
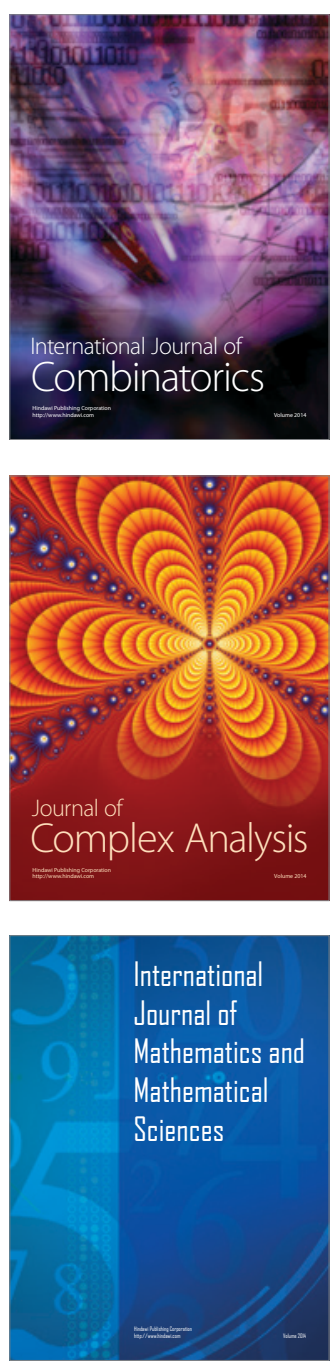
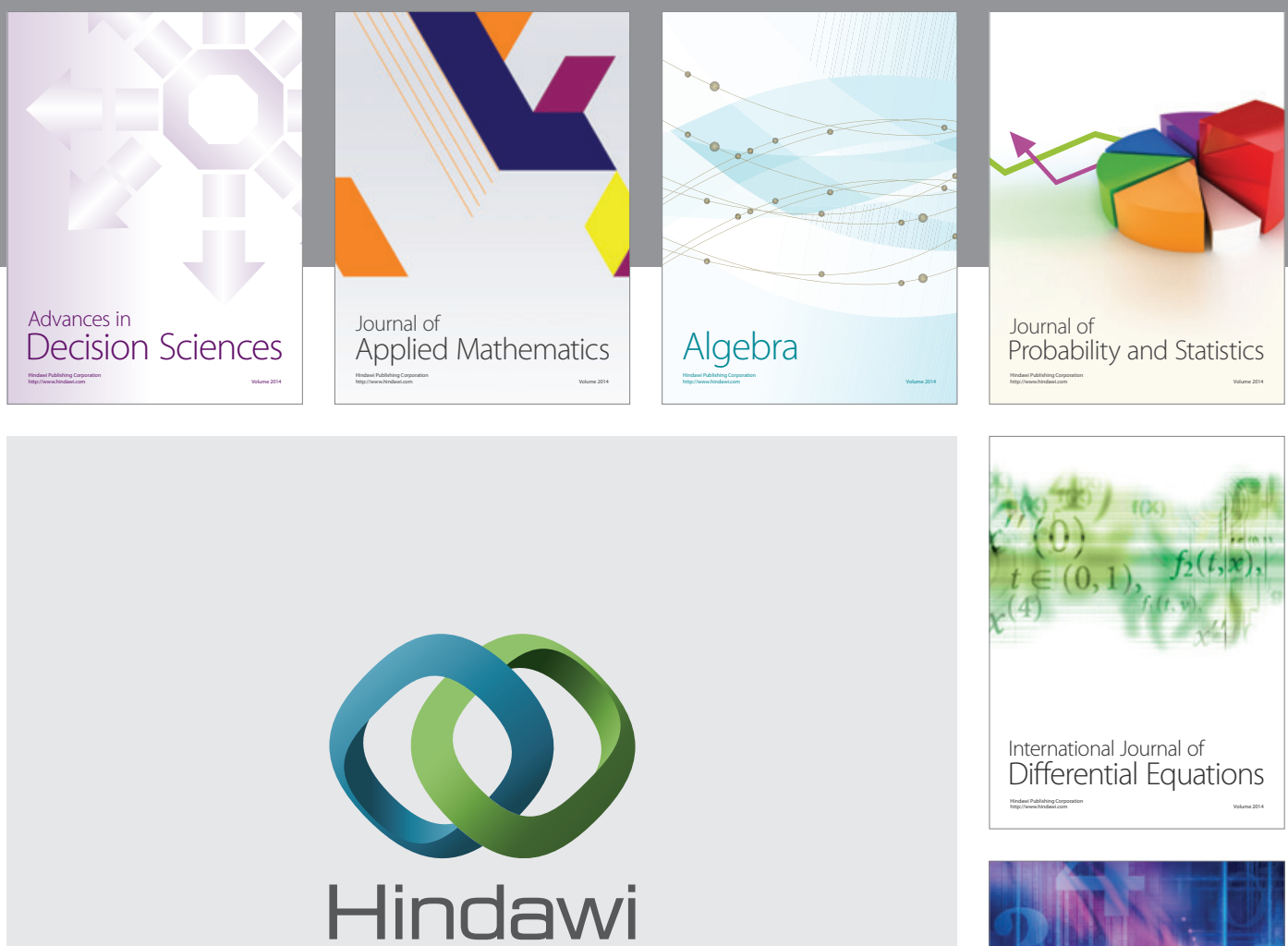

Submit your manuscripts at http://www.hindawi.com
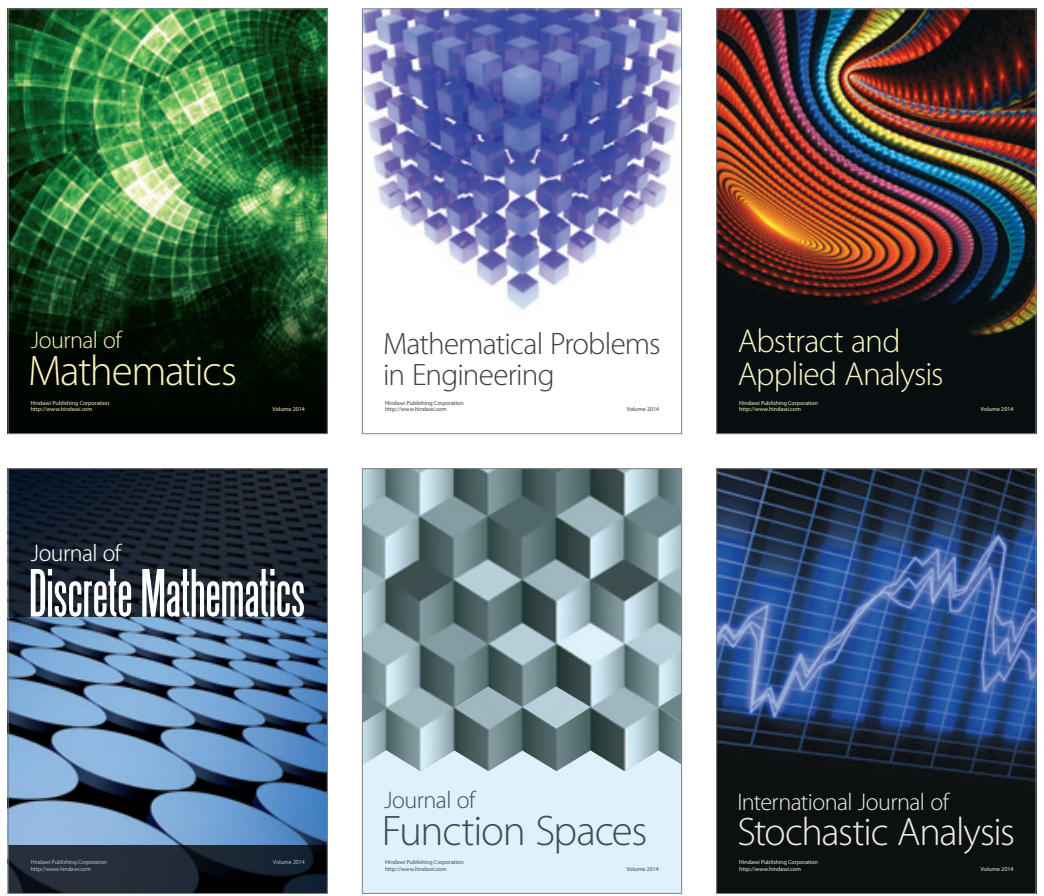

Journal of

Function Spaces

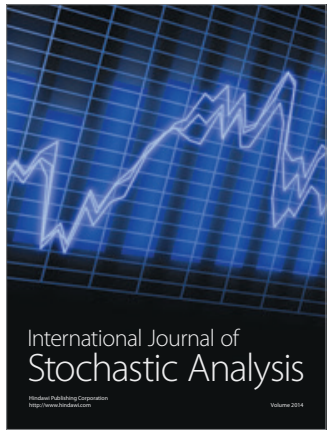

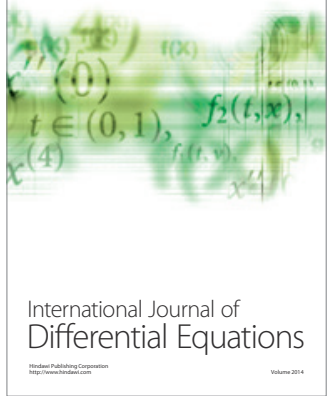
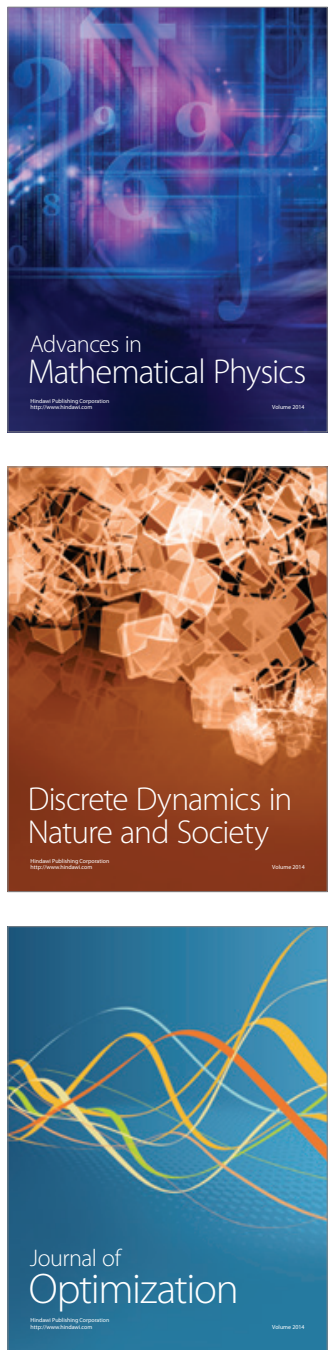